\title{
The design, synthesis, and evaluation of hypoxia-activated prodrugs of the KDAC inhibitor panobinostat
}

\author{
Ewen D. D. Calder, ${ }^{1, \neq}$ Anna Skwarska, ${ }^{2, \neq}$ Deborah Sneddon, ${ }^{1}$ Lisa K. Folkes, ${ }^{2}$ Ishna N. Mistry, ${ }^{2}$ \\ Ester M. Hammond, ${ }^{2 *}$ and Stuart J. Conway ${ }^{1 *}$ \\ ${ }^{1}$ Department of Chemistry, Chemistry Research Laboratory, University of Oxford, Mansfield Road, Oxford, OX1 3TA, UK. \\ ${ }^{2}$ Oxford Institute for Radiation Oncology, Department of Oncology, University of Oxford, Old Road Campus Research Building, Ox- \\ ford, OX3 7DQ, UK.
}

\begin{abstract}
The design and synthesis of four hypoxia-activated prodrugs of the KDAC inhibitor panobinostat is described. Initial validation of these compounds using isolated enzymes, and in two human cancer cell lines, reveals that the nitroimidazole-based prodrug (NI-Pano, CH03) undergoes efficient bioreduction and fragmentation to release the parent drug, panobinostat. NI-Pano was identified as the optimum compound for use in further studies in cells, spheroid tumor models, and in vivo.
\end{abstract}

Introduction

Protein post-translational modifications (PTMs) add a layer of complexity to the proteome and provide mechanisms to fine-tune protein function. ${ }^{1}$ Lysine acetylation is a long-known $\mathrm{PTM}^{2}$ that is found in over 3600 locations on over 1750 proteins throughout the cellular environment. ${ }^{3-4}$ Recently, there has been a particular focus on lysine acetylation in histone proteins, which play a key role in the organization of DNA in chromatin. Acetylation leads to the formation of an amide, which removes the positive charge from the $\mathcal{\varepsilon}$ nitrogen atom of lysine, resulting in a weaker association with negatively charged DNA, and the formation of euchromatin. This more relaxed form a chromatin is associated with transcriptional activation. Lysine acetylation state is regulated by histone/lysine acetyl transferase (H/KATs) enzymes, which transfer an acetyl group from AcCoA to lysine, and the mechanistically distinct sirtuin and $\mathrm{Zn}^{2+}$ - dependent histone/lysine deacetylases ( $\mathrm{H} / \mathrm{KDACs})$ that remove this mark. ${ }^{5-6}$ Bromodomains are protein modules that bind to acetyllysine (KAc) residues and in so doing mediate protein-protein and protein-chromatin interactions enabling the assembly of transcription complexes. ${ }^{7-10}$ Many examples exist of KDAC dysregulation being linked to oncogenic states in tissues throughout the body. ${ }^{11-12}$ These observations have led to significant interest in molecules that can inhibit these enzymes, culminating in the clinical approval of five KDAC inhibitors to date (belinostat, chidamide, panobinostat, romidepsin, and vorinostat). ${ }^{13-15}$ All KDAC inhibitors possess a group that binds to the $\mathrm{Zn}^{2+}$ ion found in the enzyme active site, which mimics KAc binding in the active site, and inhibits enzyme function. For belinostat, panobinostat and vorinostat this moiety is a hydroxamic acid.

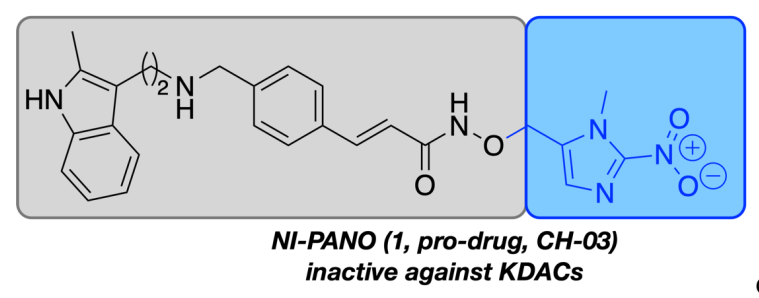

inactive against KDACs

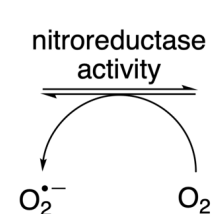

rapid back oxidation occurs under normoxia<smiles>Cc1[nH]c2ccccc2c1C=NCc1ccc(/C=C/C(=O)NOCc2cnc([N+](C)=O)n2C)cc1</smiles>

$\downarrow$ further reduction
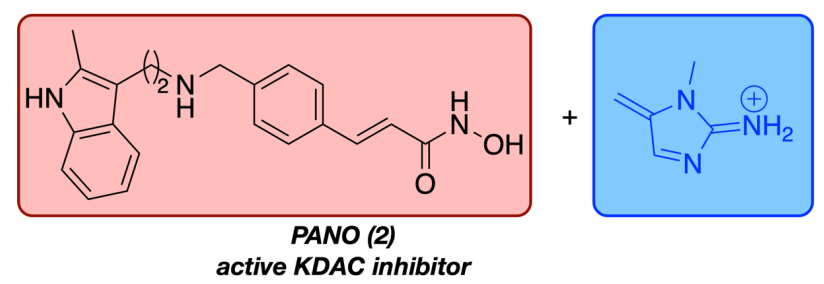

fragmentation

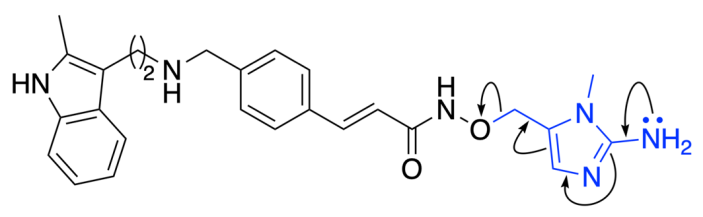

Figure 1. The concept of a hypoxia-activated prodrug of the KDAC inhibitor panobinostat. The hydroxamic acid is protected with a bioreductive group to prevent binding to the KDAC enzymes. The nitroimidazole group undergoes reduction and fragmentation in hypoxia to release the active KDAC inhibitor panobinostat. 
In addition to $\mathrm{Zn}^{2+}$, this group can bind to other metals or inhibit other off-target enzymes. Hydroxamic acids are also polar, and can hinder the diffusion of KDAC inhibitors into cells and organs, for example, the brain. In addition, KDACs are broad epigenetic remodelers that affect the transcription of many genes, in both healthy tissues and tumors. For these reasons, KDAC inhibitors have a number of documented side effects including anemia, neutropenia, thrombocytopenia, fatigue, diarrhea, nausea and vomiting. ${ }^{16-17}$ In recent years, attempts have been made to increase the selectivity of these inhibitors and therefore mitigate these unwanted effects. Work to achieve this has included both designing selective inhibitors of a given $\mathrm{KDAC}$ enzymes, or developing prodrugs that selectively release inhibitors in a target tissue. ${ }^{18-21}$ Prodrugs of KDAC inhibitors have been developed that are activated by hydrolysis, ${ }^{22}$ thiols, ${ }^{16}$ reactive oxygen species, ${ }^{23}$ hydrogen peroxide or peroxynitrate, ${ }^{24}$ esterases, ${ }^{25-26}$ light, ${ }^{27}$ and transition-metals. ${ }^{28}$ We have recently reported a prodrug of the KDAC inhibitor vorinostat (SAHA) that is selectively released in hypoxia. ${ }^{29}$
Hypoxia, or a state of insufficient oxygen $\left(<2 \% \mathrm{O}_{2}\right),{ }^{30}$ is a feature of solid tumors. ${ }^{31}$ This pathophysiological state occurs due to rapid and disordered growth of vasculature, and increased cellular proliferation and metabolic rates. Hypoxia is strongly correlated with poor patient prognosis, as hypoxic tumors show increased resistance to all forms of treatment, and higher rates of metastasis. ${ }^{32-33}$

In the absence of oxygen, radiotherapy is less effective as oxygen is required for ionizing radiation induced free radicals that damage DNA. ${ }^{34}$ In addition, some chemotherapies show lower efficacy in hypoxia due to reduced blood circulation reducing drug delivery. ${ }^{35-36}$ Cellular mechanisms for detoxification or efflux of the drug can be more active, and a difference in $\mathrm{pH}$ may preclude certain drugs from entering the tumor. ${ }^{37-39}$ So while hypoxia is detrimental to patient survival, this is the component of the tumor that we most want to treat, and the different chemical environment created by the lack of oxygen potentially allows the release of drugs selectively in these regions.

Scheme 1: Synthesis the bioreductive group precursors $5,8,12,15$.
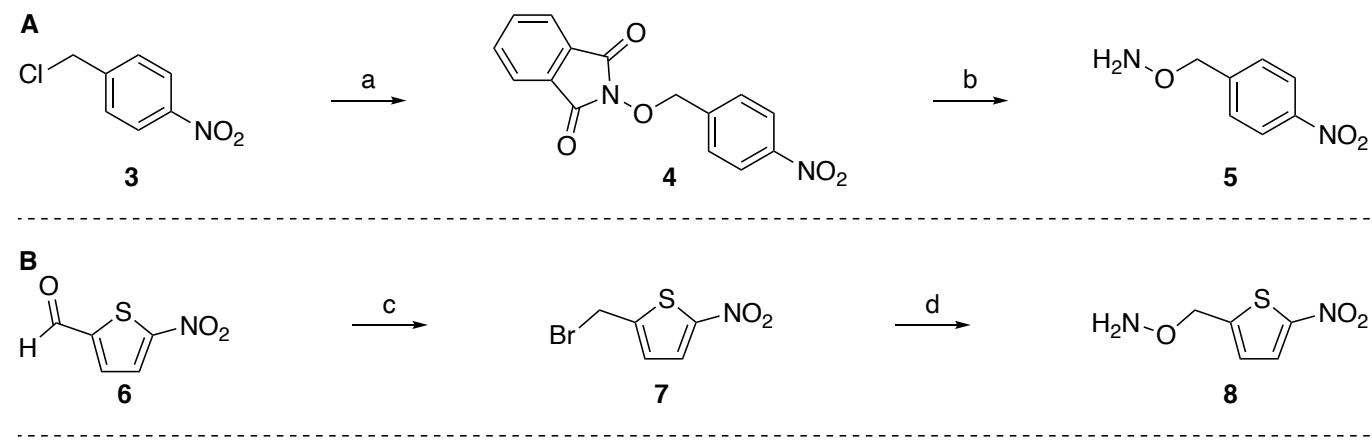

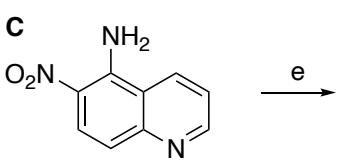

9

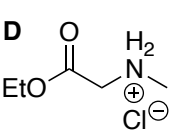

13

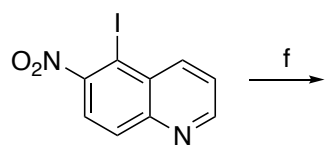

10

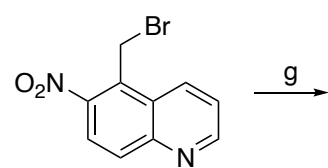

11

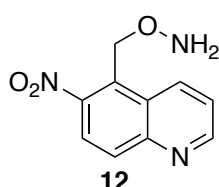

12

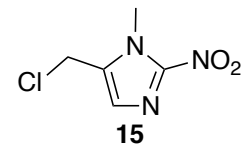

Reagents and conditions: (A) (a) N-Hydroxyphthalimide, DIPEA, DMF, $0{ }^{\circ} \mathrm{C}$ to rt, $2 \mathrm{~h}, 76-84 \%, \mathrm{n}=2$, (b) $\mathrm{N}_{2} \mathrm{H}_{4} \cdot \mathrm{H}_{2} \mathrm{O}, \mathrm{CH}_{2} \mathrm{Cl}_{2}, \mathrm{rt}, 2 \mathrm{~h}, 72-95 \%, \mathrm{n}=4$. (B) (c) (i) $\mathrm{NaBH}_{4}, \mathrm{MeOH}, 0{ }^{\circ} \mathrm{C}$ to rt, $2 \mathrm{~h}, 79-99 \%$, n=4; (ii) $\mathrm{PBr}_{3}, \mathrm{CH}_{2} \mathrm{Cl}_{2}, 0^{\circ} \mathrm{C}$ to rt, 5 h, 24-48\%, n=4; (d) (i) $N$-Hydroxyphthalimide, DIPEA, DMF, $0{ }^{\circ} \mathrm{C}$ to rt, $2 \mathrm{~h}, 47-63 \%$, n=2, (ii) $\mathrm{N}_{2} \mathrm{H}_{4} \cdot \mathrm{H}_{2} \mathrm{O}, \mathrm{CH}_{2} \mathrm{Cl}_{2}$, rt $2 \mathrm{~h}, 46 \%, \mathrm{n}=1$. (C) (e) CuI, $\mathrm{NaNO}_{2}, \mathrm{HI}$ (57\% aq.), DMSO, $60{ }^{\circ} \mathrm{C}, 0.5 \mathrm{~h}, 31-60 \%, \mathrm{n}=2$; (f) (i) $\mathrm{PhMgCl}, \mathrm{THF},-40^{\circ} \mathrm{C}, 10 \mathrm{~min}$ then $\left(\mathrm{CH}_{2} \mathrm{O}\right)_{\mathrm{n}},-40^{\circ} \mathrm{C}$ to $40^{\circ} \mathrm{C}, 18 \mathrm{~h}, 42-86 \%$, n=4; (ii) $\mathrm{HBr}\left(48 \%\right.$ aq.), $75{ }^{\circ} \mathrm{C}, 18 \mathrm{~h}, 77-99 \%, \mathrm{n}=2$; (g) (i) $N$-Hydroxyphthalimide, DIPEA, DMF, $0^{\circ} \mathrm{C}$ to rt, $2 \mathrm{~h}, 88 \%, \mathrm{n}=1$; (ii) $\mathrm{N}_{2} \mathrm{H}_{4} \cdot \mathrm{H}_{2} \mathrm{O}, \mathrm{CH}_{2} \mathrm{Cl}_{2}, \mathrm{rt} 2 \mathrm{~h}, 92 \%, \mathrm{n}=1$. (D) (h) (i) $\mathrm{NaH}, \mathrm{EtOCHO}, \mathrm{THF}, \mathrm{EtOH}, 0^{\circ} \mathrm{C}$ to rt, 18 h; (ii) $\mathrm{HCl}$ (37\% aq.), EtOH, rt, 2 h; (iii) $\mathrm{NCNH}_{2}, \mathrm{EtOH}, \mathrm{H}_{2} \mathrm{O}, 100{ }^{\circ} \mathrm{C}, 2 \mathrm{~h}, 41-79 \%$ (over 3 steps), n=5; (j) (i) $\mathrm{NaNO}_{2}, \mathrm{AcOH}_{2} \mathrm{H}_{2} \mathrm{O}, 0{ }^{\circ} \mathrm{C}$ to rt, 4 h, 57-81\%, n=5; (ii) $\mathrm{NaBH}_{4}$, EtOH, THF, $0{ }^{\circ} \mathrm{C}, 3 \mathrm{~h}, 70-80 \%$, n=5; (iii) $\mathrm{CH}_{3} \mathrm{SO}_{2} \mathrm{Cl}$, pyridine, $0{ }^{\circ} \mathrm{C}$ to rt, $3 \mathrm{~h}, 54-67 \%, \mathrm{n}=5$.

Hypoxia-activated pro-drugs (HAPs) are a class of small molecules containing a motif that is reactive in low oxygen, known as a bioreductive group. ${ }^{40-43}$ The bioreductive group is attached to the active compounds in such a way that its original biological function is minimized. Upon exposure to hypoxia the bioreductive group reacts to release the biologically active compound (Figure 1). As the reaction occurs preferentially in hypoxia, the active compound is only released in these areas. Bioreductive groups that have been employed in HAPs include nitroaromatic groups, quinones, or $\mathrm{N}$-oxides. ${ }^{40,44}$ The choice of prodrug functionality is informed both by its reduction potential and the targeted enzymatic pathway of metabolism. ${ }^{45}$ Once reduced, these functionalities undergo subsequent reactions 
to release a cargo molecule (Figure 1). Early examples of cargo molecules were mostly DNA reactive nitrogen mustards, ${ }^{46}$ however, these cytotoxic agents have compatibility issues with other forms of chemotherapy. ${ }^{47}$ This led to the development of HAPs based on small molecule inhibitors of specific protein function, including $\mathrm{CH}$ 01 (CHK-1), BCCA621C (DNA-PK), tarloxotinib (HER2), and CEP-9722 (PARP). ${ }^{48-51}$

We have recently reported developed two HAPs of the KDAC inhibitor vorinostat (SAHA) ${ }^{29}$ While the nitroimidazole-derived SAHA derivative (NI-SAHA) showed promising reduction and fragmentation properties in vitro, the half-life of the released drug, vorinostat, (1.5-2.0 h oral administration in human) was insufficient to warrant progressing the lead prodrug, nitroimidazole-SAHA (NI-SAHA) into cellular studies. ${ }^{52-53}$ The KDAC inhibitor panobinostat maintains efficacy in hypoxia ${ }^{5}$ and shows a longer half-life $(16.9 \mathrm{~h}$, oral administration in human) compared to vorinostat. ${ }^{54}$ Here, we describe the design, synthesis, and validation of four panobinostat-based HAPs.

Scheme 2. General Synthesis of HAP Analogues of Panobinostat (24-26) and the negative control compound (23).

A<smiles>COC(=O)/C=C/c1ccc(CN=Cc2c(C)[nH]c3ccccc23)cc1</smiles>

16
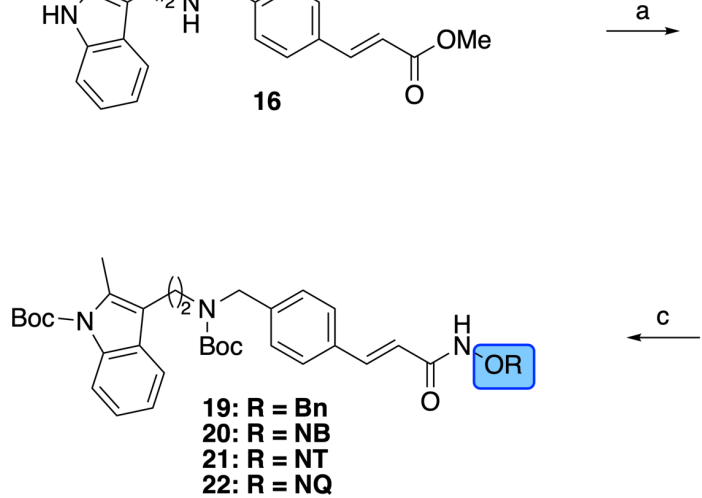<smiles>COC(=O)/C=C/c1ccc(CN(Cc2ccccc2)C(=O)c2ccccc2)cc1</smiles>

b
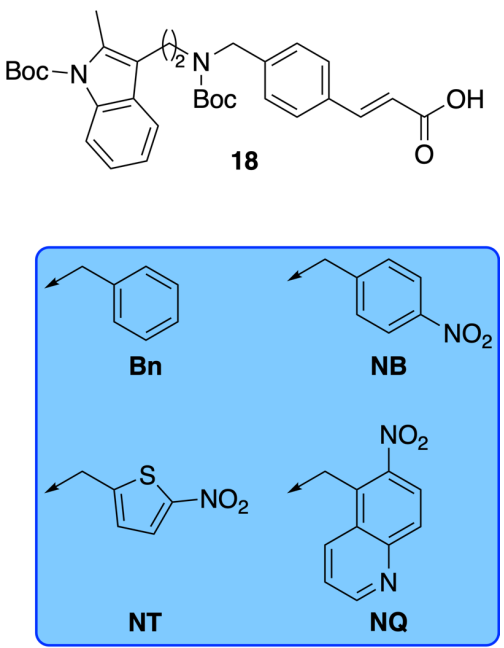

B<smiles>Cc1c(C=NCc2ccccc2)c2ccccc2n1C(=O)OC(C)(C)C</smiles>

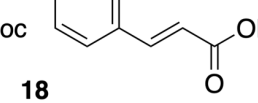

18

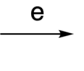

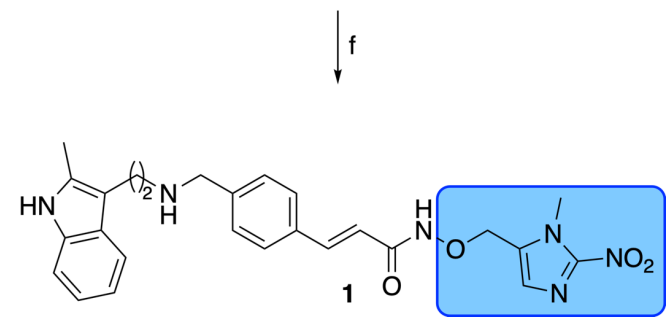

Reagents and conditions: (A) (a) $\mathrm{Boc}_{2} \mathrm{O}$, DMAP, THF, rt, 18 h, 67-82\%, n=5; (b) LiOH, THF, MeOH, $\mathrm{H}_{2} \mathrm{O}, \mathrm{rt}, 6 \mathrm{~h}, 88-83 \%$, n=5; (c) RONH ,

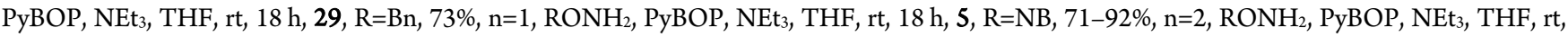
$18 \mathrm{~h}, 8, \mathrm{R}=\mathrm{NT}, 62-84 \%$, n=2, RONH 2 , PyBOP, NEt 3 , THF, rt, 18 h, 12, R=NQ, 60\%, n=1; (d) TFA, TIPS-H, CH $\mathrm{Cl}_{2}, \mathrm{rt}, 1 \mathrm{~h}, 19, \mathrm{R}=\mathrm{Bn}, 79 \%, \mathrm{n}=1$, TFA, TIPS-H, $\mathrm{CH}_{2} \mathrm{Cl}_{2}$, rt, 1 h, 20, R=NB, 68-69\%, n=2, TFA, TIPS-H, $\mathrm{CH}_{2} \mathrm{Cl}_{2}, \mathrm{rt}, 1$ h, 21, R=NT, 52-64\%, n=2, TFA, TIPS-H, CH $\mathrm{Cl}_{2}, \mathrm{rt}, 1 \mathrm{~h}, 22$, $\mathrm{R}=\mathrm{NQ}, 40 \%$, n=1. (B) (e) CDI, THF, rt, $1 \mathrm{~h}$ then $\mathrm{HONH}_{3} \mathrm{Cl}, \mathrm{rt}, 18 \mathrm{~h}, 51-63 \%, \mathrm{n}=4$; (f) (i) $\mathrm{NaH}, \mathrm{DMF},-5^{\circ} \mathrm{C}, 20 \mathrm{~min}$ then $15,-5^{\circ} \mathrm{C}$ to rt, $18 \mathrm{~h}, 71-$ $86 \%, \mathrm{n}=4$, (ii) TFA, TIPS-H, $\mathrm{CH}_{2} \mathrm{Cl}_{2}, \mathrm{rt}, 1 \mathrm{~h}, 51-61 \%$, $\mathrm{n}=4$. 
Initial characterization in vitro and in cells described here, identified the nitroimidazole-derived panobinostat prodrug (NI-Pano, 1) as the most promising compound for further evaluation. Subsequent work on this compound, which has recently been published elsewhere, ${ }^{55}$ demonstrates that NI-Pano is an effective KDAC-targeting HAP in an esophageal squamous cancer cell line (OE21)-derived mouse tumor xenograft model. Treatment of xenograft-bearing mice resulted in a substantial tumor growth delay compared to untreated mice, and preferential release of panobinostat in the tumor compared to plasma and kidney.

\section{Results and discussion}

\section{Design and synthesis of the prodrugs}

$\mathrm{We}$, and others, have previously demonstrated, blocking the oxygen atom of the hydroxamic acid of disrupts binding to the KDAC enzymes. ${ }^{29}$ This ensures that the prodrug is inactive until the drug is released at the desired time and/or location. Four nitroaromatic groups were chosen as the bioreductive moieties to attach to the hydroxamic acid. The nitrobenzyl (NB), nitrothiophene (NT) and nitroimidazole (NI) groups have previously been employed by $\mathrm{us}^{29,45}$, 48, 56-57 and others ${ }^{40,42,44,49,58-60}$ as bioreductive group in HAPs, and have a range of bioreduction potentials. ${ }^{45} \mathrm{We}$ also investigated the use of the nitroquinoline (NQ) group, which we predicted would have bioreduction properties similar to the NI group. A negative control compound was designed, in which the bioreductive group was replaced with a simple benzyl moiety, which is inert to reduction and consequently fragmentation. We initially proposed that the synthesis of the nitroaromatic-functionalized hydroxylamines would allow a convergent route to all of these molecules.

Panobinostat was synthesized using a route that has previously been reported in the literature with minor modification made (Scheme S1 and SI for details) ${ }^{61} \mathrm{~A}$ Grandberg reaction of phenylhydrazine with the chloroketone $\mathbf{S} 1$ gave 2-methyltryptamine (S2) ${ }^{62-64}$ A MizorokiHeck reaction of 4-bromobenzaldehyde (S3) with methyl acylate yielded the aldehyde $\mathbf{S 4}$, which was subsequently underwent a reductive amination with the primary amine of $\mathbf{S} 2$ in a to give 16 . Displacement of the methyl ester with hydroxylamine gave panobinostat (2).

While the benzyl-hydroxylamine (29) was commercially available, the remaining functionalized hydroxylamines were synthesized as shown in Scheme 2. Briefly, reaction of $N$-hydroxyphthalimide with 4-nitrobenzyl chloride (3) followed by deprotection with hydrazine gave nitrobenzyl hydroxylamine 5 . To form the thiophene analogue (8), the commercially available 5-nitrothiophene-2-carboxaldehyde (6) was first reduced to the alcohol, and then brominated with phosphorus tribromide to give 7 . The bromide was displaced with $N$-hydroxyphthalimide, and hydrazine deprotection gave 8 . The nitroquinoline bromide has previously been synthesized by our group, however, an alternative route was used here. ${ }^{57}$ Sandmeyer iodination of 5-amino-6-nitroquinoline (9) gave the iodide 10. Grignard exchange with phenyl magnesium bromide, followed by addition of paraformaldehyde yielded the primary alcohol, which was brominated with hydrobromic acid to give the bromide 11. Following the same steps used for the nitrobenzyl and nitrothiophene analogues gave the nitroquinoline-functionalized hydroxylamine 12 . The nitroimidazole chloride (15) was synthesized in 6 steps using a route similar to that we have previously reported. ${ }^{29}$ However, the nitroimidazole-containing hydroxylamine derivative was unstable, meaning that the chloronitroimidazole (15) was coupled to panobinostat using an alternative procedure (vide infra).

To synthesize the panobinostat prodrugs, protection of both nitrogen atoms in the core molecule was necessary (Scheme 2). Boc protection of the methyl ester 16 (Scheme 2A), followed lithium hydroxide-catalyzed hydrolysis, gave the carboxylic acid 17. Coupling with the functionalized hydroxylamines 5, 8, 12 and 29, using PyBOP, followed by deprotection with trifluoroacetic acid, yielded the inactive control 23 and three of the prodrugs 24-26. CDI-mediated coupling of the carboxylic acid $\mathbf{1 8}$ with hydroxylamine hydrochloride yielded di-Boc-protected panobinostat, 27. This compound was alkylated with the nitroimidazole halide 15 , and deprotected using TFA and TIPS-H gave NI-Pano 1 (Scheme 2B).

\section{Biological evaluation of the prodrugs}

To determine if the prodrugs 1, 24-26 underwent hypoxia dependent reduction and fragmentation, the four HAP analogues, panobinostat (2), and the negative control Bn-Pano (23), were incubated with NADPH-CYP reductase (CYP004) in normoxic and hypoxic conditions for up to 24 hours. We have previously used this procedure as an initial stage of prodrug validation, and it shows good correlation with cellular activity. ${ }^{45,48,56}$ The prodrug reduction and release of panobinostat was monitored using LCMS, as described previously. ${ }^{29,65}$ As expected, neither Bn-Pano (23) nor panobinostat (2) were reduced in normoxic or hypoxic conditions (Figure 3A, B). NB-Pano (24) appeared stable in both normoxia and hypoxia with no apparent production of panobinostat (Figure $3 \mathrm{C}$ ). In previous studies, a higher concentration of enzyme ( $92 \mathrm{pmol} / \mathrm{mL}, 10$-fold) has been used to reduce the NB group, as this moiety is more stable to bioreduction than other groups. ${ }^{29,48,56}$ With the increased enzyme concentration, panobinostat was produced in hypoxia (Figure S1). We have found, however, that the lower enzyme concentration translates well to levels and rates of cellular reduction for this class of compounds, indicating that NB-Pano might not be optimum for cellular and in vivo studies.

Panobinostat release from NT-Pano (25) was observed in both normoxic and hypoxic conditions (Figure 2D). Although more panobinostat was released in hypoxia, to be suitable for cellular and in vivo studies, there should be no released of panobinostat in this assay. The levels of NQ-Pano (26) were depleted in both normoxic and hypoxic conditions. However, unlike NT-Pano, NQ-Pano did not release panobinostat under normoxic conditions (Figure 2E). This suggests that some metabolism of NQ-Pano can occur in normoxia, but that fragmentation to release the free drug does not occur. It is possible that NQ-Pano undergoes partial reduction to one of the intermediate reduced states, without fragmentation to release panobinostat. Partial reduction to intermediates including the nitroso, and full reduction to the amine without fragmentation has been observed with a nitrobenzyl group in hypoxia. ${ }^{48}$ However, in this case these intermediates could not be observed by LCMS. 
A

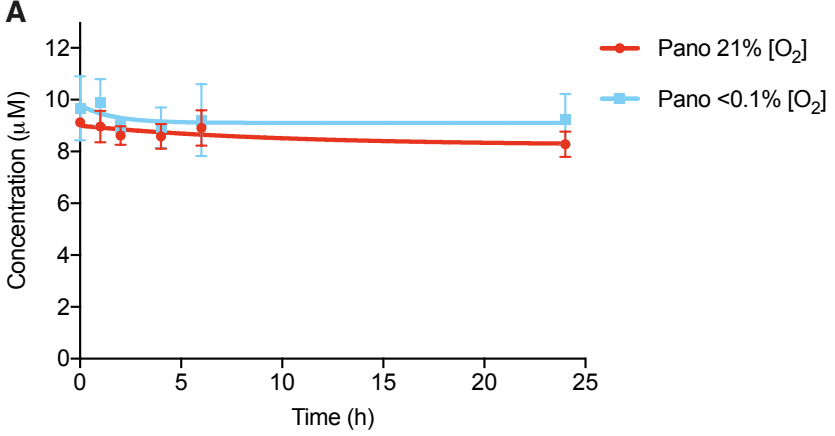

C

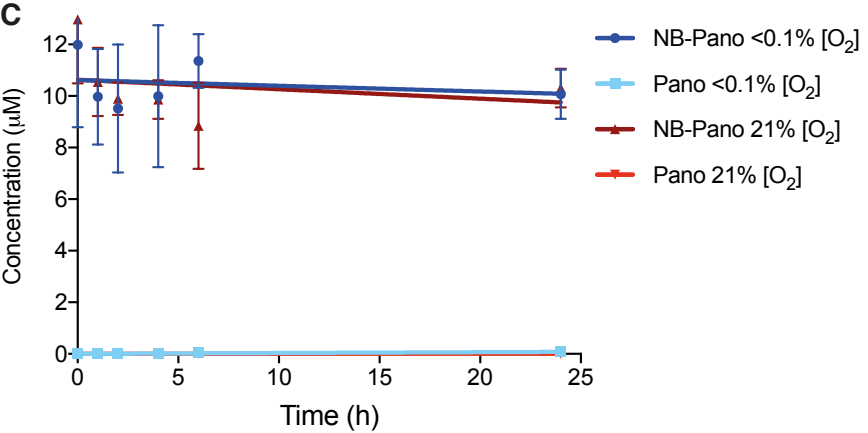

E

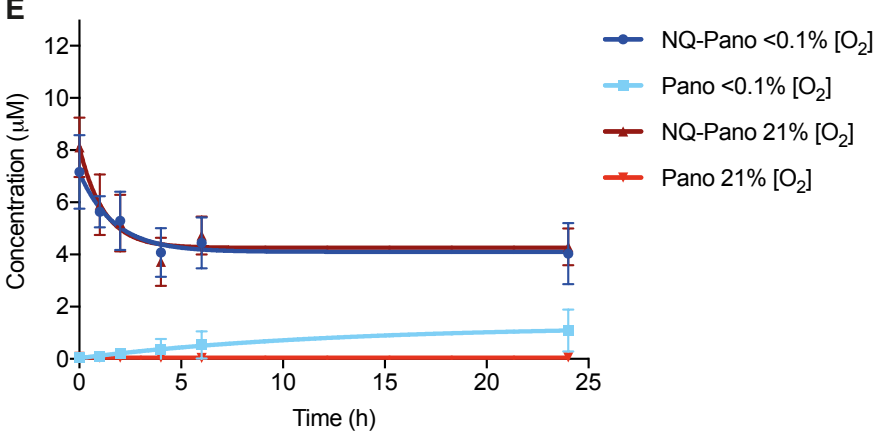

B

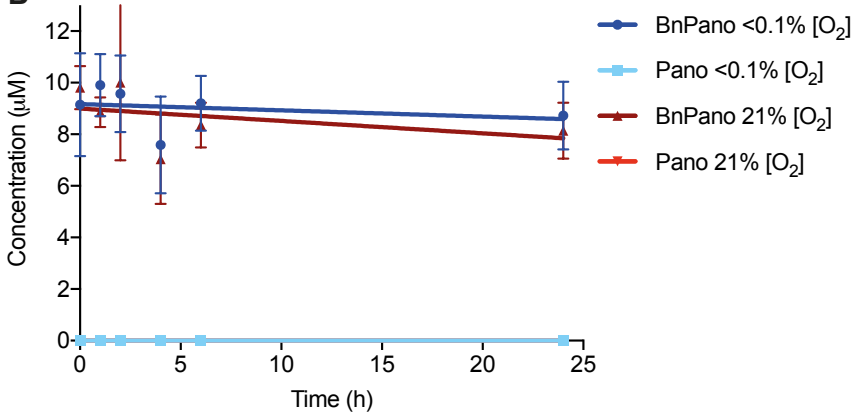

D

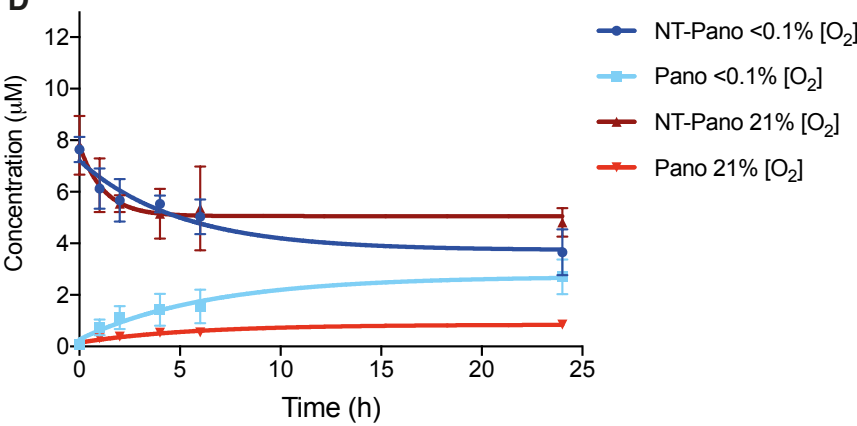

$\mathbf{F}$

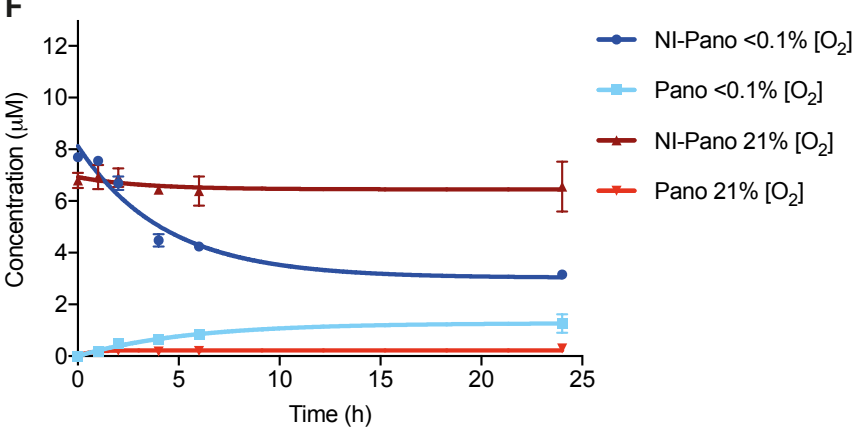

Figure 2. Oxygen dependent reduction and fragmentation of HAPs of panobinostat. (A) Bn-Pano (10 $\mu \mathrm{M}),($ B) panobinostat (10 $\mu \mathrm{M})$, (C) NB-Pano $(10 \mu \mathrm{M}),(\mathbf{D})$ NT-Pano $(10 \mu \mathrm{M}),(\mathbf{E})$ NQ-Pano $(10 \mu \mathrm{M})$ and $(\mathbf{F})$ NI-Pano $(10 \mu \mathrm{M})$ were incubated with $9.2 \mathrm{pmol} / \mathrm{mL}$ of bactosomal NADPH-CYP reductase $(\mathrm{CYP} 004)$ in normoxic $\left(21 \% \mathrm{O}_{2}\right)$ or hypoxic $\left(<0.1 \% \mathrm{O}_{2}\right)$ conditions for $0-24 \mathrm{~h}$ and analyzed using LCMS. Data are mean $\pm \mathrm{SD}$, $\mathrm{n}=3 \mathrm{except}$ $\mathrm{B}$, which is $\mathrm{n}=2$.

NI-Pano (1) was stable in normoxic conditions and did not release detectable panobinostat, however, in hypoxic conditions a clear increase in panobinostat was observed (Figure 2F). This observation is in line with our previous work in which we demonstrated an NIbased HAP of SAHA can undergo bioreduction and fragmentation in the presence of NADPH-CYP reductase (CYP004). Therefore, of the panobinostat-based HAPs synthesized and tested, NQ-Pano (26) and NI-Pano (1) were found to have the most encouraging and selective reduction and release profiles and were progressed for further evaluation.

We have previously shown that neither NB-SAHA nor NI-SAHA showed any inhibition of a panel of ten $\mathrm{Zn}^{2+}$-dependent KDAC enzymes. We used the same enzyme assay (Reaction Biology) to determine whether the addition of the NQ and NI groups would prevent panobinostat inhibiting these enzymes. Panobinostat has previously been shown to be a very effective inhibitor of all KDAC enzymes. ${ }^{66}$ While NQ-Pano retained some inhibitory activity against KDAC1-3 and KDAC6, NI-Pano showed weak or no inhibitory activity against any of the KDAC enzymes tested (Table 1).

It initially appears surprising that the NQ group is tolerated by these enzymes, while the NI group is not. As the activity shown by NQPano was not observed for all enzymes, it is reasonable to assume that these data are meaningful, and not a result of assay interference. Analysis of the X-ray crystal structures of KDAC1-3 and $\mathrm{KDAC6}^{67}$ ${ }^{72}$ shows that they have larger active site pockets than the other KDACs. KDAC1-3 have been shown to accommodate aromatic groups into the active site pocket, for example the selective biaryl benzamide KDAC inhibitors. ${ }^{73-74}$ The nitro moieties of the NI and NQ groups have different vectors, meaning that they will extend into different areas of the enzyme active site. Our current hypothesis is that the vector of the nitro group of the NI group is particularly unfavorable for enzyme binding, making it an effective bioreductive group for HAPs targeting the KDAC enzymes. 


\begin{tabular}{c|cccccccccc}
\hline & \multicolumn{10}{|c}{$\mathrm{IC}_{50}(\mathrm{nM})^{\mathrm{a}}$} \\
\hline Compound & KDAC1 & KDAC2 & KDAC3 & KDAC4 & KDAC5 & KDAC6 & KDAC7 & KDAC8 & KDAC9 & KDAC11 \\
\hline Pano (2) & $\begin{array}{c}0.31 \\
\pm 0.05\end{array}$ & $\begin{array}{c}1.51 \\
\pm 0.20\end{array}$ & $\begin{array}{c}1.69 \\
\pm 0.20\end{array}$ & $\begin{array}{c}0.42 \\
\pm 0.08\end{array}$ & $\begin{array}{c}0.84 \\
\pm 0.17\end{array}$ & $\begin{array}{c}1.98 \\
\pm 0.28\end{array}$ & $\begin{array}{c}38.6 \\
\pm 13.2\end{array}$ & $\begin{array}{c}38.9 \\
\pm 10.0\end{array}$ & $\begin{array}{c}1.65 \\
\pm 0.14\end{array}$ & $\begin{array}{c}0.32 \\
\pm 0.03\end{array}$ \\
\hline NQ-Pano (26) & 87.2 & 559 & 69.8 & $\mathrm{NI}$ & $\mathrm{NI}$ & 1548 & $\mathrm{NI}$ & $\mathrm{NI}$ & $\mathrm{NI}$ & $\mathrm{NI}$ \\
\hline NI-Pano (1) & $\begin{array}{c}2290 \pm \\
1521\end{array}$ & $\begin{array}{c}5810 \pm \\
3528\end{array}$ & $\begin{array}{c}1390 \pm \\
766\end{array}$ & $\mathrm{NI}$ & $\mathrm{NI}$ & $\begin{array}{c}2880 \pm \\
1285\end{array}$ & $\mathrm{NI}$ & $\mathrm{NI}$ & $\mathrm{NI}$ & $\mathrm{NI}$ \\
\hline $\begin{array}{c}\text { NI-Pano/Pano } \\
\text { Selectivity }\end{array}$ & 7387 & 3848 & 822 & - & - & 1455 & - & - & - & - \\
\hline
\end{tabular}

$\mathrm{IC}_{50}$ values $(\mathrm{nM})$ for panobinostat and NI-Pano against KDAC1-9 and KDAC11. The color scale represents a heat map, with 'hot' colors showing effective enzyme inhibition. ${ }^{a}$ Data obtained by Reaction Biology Corporation, NI = no inhibition observed at concentrations up to $10 \mu \mathrm{M}$. ${ }^{\mathrm{b}} \mathrm{Data}$ taken from Arts et al. ${ }^{66 \mathrm{c}} \mathrm{n}=2$ biological repeats for all enzymes, value shown is the mean \pm S.E.M.

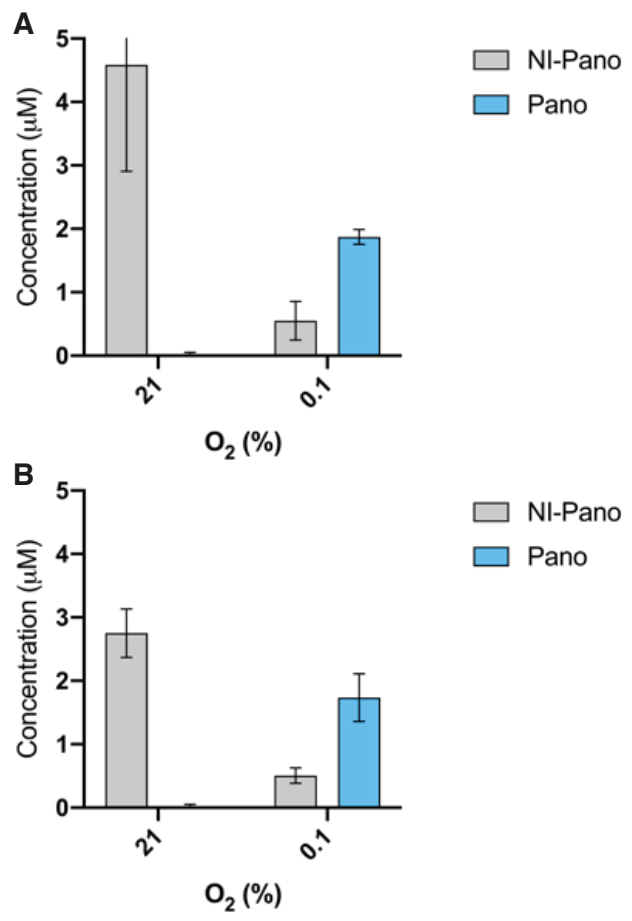

Figure 3. Hypoxia-dependent reduction of NI-Pano to release panobinostat in the (A) FLO-1 and (B) HCT116 cell lines. Cells were incubated with $5 \mu \mathrm{M}$ NI-Pano in normoxic $\left(21 \% \mathrm{O}_{2}\right)$ or hypoxic $\left(<0.1 \% \mathrm{O}_{2}\right)$ conditions for $6 \mathrm{~h}$. Cells were collected, lysed and compounds extracted in $\mathrm{MeOH} / \mathrm{MeCN}$ and samples analyzed using LCMS. Quantification of three independent repeats relative to standard curves for each compound is shown. Data are mean $\pm \operatorname{SD}(n=3)$.

To investigate the efficiency of release of panobinostat in cells, the FLO-1 oesophageal adenocarcinoma cell line or the colon cancer HCT-116 cell line were incubated with NI-Pano in normoxic $(21 \%$ $\left.\mathrm{O}_{2}\right)$ or hypoxic $\left(<0.1 \% \mathrm{O}_{2}\right)$ conditions for $6 \mathrm{~h}$. The cells were then lysed and the lysate analyzed using LCMS (Figure 3 ). In 21\% oxygen, only the NI-Pano prodrug was detected in both cell lines. How- ever, in $<0.1 \% \mathrm{O}_{2}$ less NI-Pano was detected and a significant quantity of free panobinostat was present. These data show that NI-Pano is able to enter these cells, as reduction takes place in the cytosol. They also show that NI-Pano can undergo reduction and fragmentation in two different cell lines to release free panobinostat. This makes NI-Pano an excellent candidate for investigation in further cancer cell lines, and more intact tumor models including spheroids and tumor xenografts.

Conclusion

Here we report the design, and synthesis of four prodrugs of the panKDAC inhibitor panobinostat and a benzylated panobinostat derivative that acts as a negative control compound. The synthetic route that we have developed is efficient and provides two options for the addition of masking groups onto the hydroxamic acid of panobinostat, and related KDAC inhibitors. We show that that optimum bioreductive release was observed from the NI-Pano and NQ-Pano derivatives, which were progressed for further studies. Addition of the NI group to panobinostat effectively abolished binding of the prodrug to all KDAC enzymes. Surprisingly, NQ-Pano retains sub-micromolar inhibitory activity against $\mathrm{KDAC} 1-3$ and some activity against KDAC6. We have attributed this activity to KDAC1-3 and KDAC6 having larger active site pockets that can accommodate the orientation of the NQ group but not the NI group. NI-Pano was assessed in the FLO- 1 and HCT-116 cancer cell lines, and shown to be stable over $6 \mathrm{~h}$ in $21 \% \mathrm{O}_{2}$, but release significant amounts of free panobinostat in $<0.1 \% \mathrm{O}_{2}$.

Based on the data presented here, we progressed NI-Pano to further cellular studies, and analysis in an in vivo tumor xenograft model. This recently published work ${ }^{55}$ demonstrates that NI-Pano releases free panobinostat in a hypoxia-dependent manner in the OE21 esophageal squamous cancer cell line, and in the hypoxic core of OE21-derived spheroids. Release of NI-Pano in these spheroids reduced their growth over a 9-day period, while those exposed to the negative control compound (Bn-Pano) continued to grow at the same rate as DMSO-treated spheroids. Analysis of H3K9Ac and $\mathrm{H} 3 \mathrm{~K} 56 \mathrm{Ac}$ levels showed that these marks increase in the spheroids 
treated with NI-Pano, but not those treated with Bn-Pano. This indicate that the toxicity observed was as a result of KDAC inhibition and subsequent apoptosis. In an OE21-derived mouse tumor xenograft model we showed that sufficient concentrations of panobinostat were released in the tumors to inhibit the KDACs, while panobinostat levels were virtually undetectable in mouse plasma or kidney. While tumors in untreated mice grew quickly and reached end point size in less than two weeks, significant tumor growth delay (828 days) was observed in mice treated with NI-Pano. These data support the hypothesis that NI-Pano preferentially releases panobinostat in tumors, and minimizes the release of the drug elsewhere in the body. Based on these data, NI-Pano is a prototypical example of an hypoxia-activated prodrug of a KDAC inhibitor. This work supports further development of NI-Pano as a promising strategy for developing clinically effective KDAC inhibitors that show reduced side effects in patients.

\section{AUTHOR INFORMATION}

\section{Corresponding Authors}

*Stuart Conway (stuart.conway@chem.ox.ac.uk) and Ester Hammond (ester.hammond@oncology.ox.ac.uk).

\section{Present Addresses}

Ewen D. D. Calder, Francis Crick Institute, 1 Midland Rd, Somers Town, London NW1 1AT, UK.

\section{Author Contributions}

The manuscript was written by E.D.D.C., E.M.H. and S.J.C. All authors have given their approval to the final version of the manuscript. ${ }^{*}$ These authors contributed equally to this work.

\section{Funding Sources}

Medical Research Council for funding (MR/N009460/1)

Engineering and Physical Sciences Research Council (EP/S019901/1)

\section{ACKNOWLEDGMENT}

E.D.D.C., I.N.M., A.S., S.J.C., and E.M.H. thank the Medical Research Council for funding (MR/N009460/1). S.J.C., D.S. and E.M.H thank the Engineering and Physical Sciences Research Council for Programme Grant support (EP/S019901/1). E.M.H. received research funding from Cancer Research UK. S.J.C. thanks St Hugh's College, Oxford, for research support. The authors thank Dr Nicola Farrer for use of her HPLC equipment.

\section{Experimental section}

NADPH reductase/CYP450 Assay. Bactosomal human NADPHCYP reductase ( 9.2 or $92 \mathrm{pmol} / \mathrm{mL}$, CYP004, Cypex) were used in combination with NADPH-regenerating system (A 451220 and $\mathrm{B}$ 451200 , Corning) as previously described. ${ }^{45}$ Enzymatic reactions were carried out in glass vials under normoxic $\left(21 \% \mathrm{O}_{2}\right)$ or hypoxic $\left(<0.1 \% \mathrm{O}_{2}\right)$ conditions. Aliquots $(50 \mu \mathrm{L})$ were taken at different time points and immediately quenched with $\mathrm{MeCN}(50 \mu \mathrm{L})$. After centrifugation samples were analyzed by LCMS. LCMS analysis was performed on a Waters 2695 system comprising an RPB column $\left(5 \mu \mathrm{m}, 100 \mathrm{~mm} \times 3.2 \mathrm{~mm}, 35^{\circ} \mathrm{C}\right)$. Separation was achieved at a flow rate of $0.5 \mathrm{~mL} / \mathrm{min}$ with a gradient of $5-95 \%$ acetonitrile in $0.1 \%$ aqueous trifluoroacetic acid over 12 minutes, returning to starting conditions over 0.1 minute. Detection used a photodiode array spectrophotometer (Waters 2996) and a mass spectrometer (Waters Micromass ZQ mass spectrometer). Cellular reduction of NI-Pano.
Cells were incubated with NI-Pano under normoxic or hypoxic condition, washed twice with PBS, collected by scraping and centrifugation. The cell pellet was mixed with $100 \mu \mathrm{L} \mathrm{MeOH} / \mathrm{MeCN}(1: 1)$, briefly sonicated and centrifuged to remove cell debris. Resulting supernatants were analyzed by HPLC. HPLC analysis was performed on a Waters 2695 system comprising an RPB column $(5 \mu \mathrm{m}, 100 \mathrm{~mm}$ $\times 3.2 \mathrm{~mm}, 35{ }^{\circ} \mathrm{C}$ ). Separation was achieved at a flow rate of 0.5 $\mathrm{mL} / \mathrm{min}$ with a gradient of 5-95\% acetonitrile in $0.1 \%$ aqueous trifluoroacetic acid over 12 minutes, returning to starting conditions over 0.1 minute. Detection used a photodiode array spectrophotometer (Waters 2996). Injections of $10 \mu \mathrm{L}$ were made.

Chemicals were purchased from Acros Organics, Alfa Aesar, Apollo Scientific, Fisher Scientific, Fluka, Fluorochem, Merck or Sigma Aldrich and were used without further purification. Where appropriate and if not otherwise stated, all non-aqueous reactions were carried out under an inert atmosphere of argon, using flame-dried glassware. Anhydrous solvents were obtained under the following conditions: THF, acetonitrile, dichloromethane, diethyl ether and DMF were dried by passing them through a column of active basic alumina according to Grubbs' procedure and stored over activated 3 Å molecular sieves under argon. ${ }^{75}$ Anhydrous methanol and ethanol was purchased from Sigma Aldrich UK in SureSeal ${ }^{\text {Ts }}$ bottles and used without further purification. Analytical thin layer chromatography (TLC) was performed on normal phase Merck silica gel 60 F254 aluminum-supported thin layer chromatography sheets. Spots were visualized by either absorption under UV light $(254 \mathrm{~nm})$, exposure to iodine vapor or thermal development after dipping into a solution of ammonium molybdate in sulfuric acid, an aqueous solution of potassium permanganate or an ethanolic solution of ninhydrin. Reaction progress was monitored at appropriate times using TLC analysis. Normal phase silica gel flash column chromatography was performed manually using Geduran Silicagel 60 (40-63 $\mu \mathrm{m})$ under a positive pressure of compressed nitrogen or on a Biotage SP1 automated column chromatography system using KP-Sil ${ }^{\odot}$ SNAP Flash Silica Cartridges. ${ }^{1} \mathrm{H}$ NMR spectra were recorded on a Bruker AVIIIHD $400(400 \mathrm{MHz})$ a Bruker AVII 500 with dual ${ }^{13} \mathrm{C}\left({ }^{1} \mathrm{H}\right)$ cryoprobe $(500 \mathrm{MHz})$ or a Bruker AVIIIHD $500(500 \mathrm{MHz})$ spectrometer with the stated solvents as a reference for the internal deuterium lock. Chemical shifts are reported as $\delta_{\mathrm{H}}$ in parts per million (ppm) relative to tetramethylsilane (TMS). The spectra are calibrated using the solvent peak with the data provided by Fulmer et al. ${ }^{76}$ Identical proton coupling constants are averaged in each spectrum and reported to the nearest $0.1 \mathrm{~Hz}$. The coupling constants were determined by analysis using Bruker TopSpin software (versions 3.2 and 4.0) or Mestrenova software (version 11). ${ }^{1} \mathrm{H}$ spectra were assigned using 2D NMR experiments including ${ }^{1} \mathrm{H}-{ }^{1} \mathrm{H}$ COSY, ${ }^{13} \mathrm{C}-{ }^{1} \mathrm{H}$ HSQC and ${ }^{13} \mathrm{C}-{ }^{1} \mathrm{H}$ HMBC. ${ }^{13} \mathrm{C}$ NMR spectra were recorded on a Bruker AVIIIHD $400(101 \mathrm{MHz})$ or a Bruker AVII 500 with dual ${ }^{13} \mathrm{C}\left({ }^{1} \mathrm{H}\right)$ cryoprobe $(126 \mathrm{MHz})$ spectrometer in the stated solvents with broadband proton decoupling and an internal deuterium lock. Chemical shifts are reported as $8 \mathrm{c}$ in parts per million (ppm) relative to tetramethylsilane (TMS). The spectra are calibrated using the solvent peak with the data provided by Fulmer et al. ${ }^{76}$ The shift values of resonances are quoted to 1 decimal place unless peaks have similar chemical shifts, in which case 2 decimal places are used. ${ }^{13} \mathrm{C}$ spectra were assigned using $2 \mathrm{D}$ NMR experiments including HSQC and ${ }^{13} \mathrm{C}-{ }^{1} \mathrm{H}$ HMBC. Electrospray ionization (ESI) mass spectra were acquired using an Agilent 6120 Quadrupole spectrometer or Waters LCT Premier spectrometer, operating in positive or negative mode, as indicated, from solutions of $\mathrm{MeOH}$ or $\mathrm{MeCN}$. 
Chemical ionization (CI) mass spectra were acquired using a Waters GCT spectrometer. MS data was processed using Mestrenova software (version 11). $\mathrm{m} / z$ values are reported in Daltons and followed by their percentage abundance in parentheses. Accurate mass spectra were obtained using Bruker $\mu$ TOF spectrometer. $\mathrm{m} / z$ values are reported in Daltons. When a compound was not observed by LRMS, only HRMS is quoted. Melting points were determined using either a Griffin capillary tube melting point apparatus or a Kofler hot stage and are uncorrected. The solvent(s) from which the sample was crystallized is given in parentheses. Infrared (IR) spectra were obtained either from neat samples, either as liquids or solids, or as a thin film using a diamond ATR module. The spectra were recorded on a Bruker Tensor 27 spectrometer. Absorption maxima are reported in wavenumbers $\left(\mathrm{cm}^{-1}\right)$. Only the main, relevant peaks have been assigned. Semi-preparative HPLC purification of NI-Pano was carried out on Waters Autopurification system, equipped with a Waters Atlantis T3 column $(19 \mathrm{~mm} \times 100 \mathrm{~mm}, 5 \mu \mathrm{m})$, with an injection loop of $1 \mathrm{~mL}$, eluting with $\mathrm{H}_{2} \mathrm{O}+0.1 \%$ TFA/MeOH $+0.1 \%$ TFA. The crude samples (in $\mathrm{MeOH}, \mathrm{DMSO}<10 \%$ ) were filtered (nylon, $0.2 \mu \mathrm{m}$ ) and injected in $750 \mu \mathrm{L}$ aliquots, with mass-directed purification with an ACQUITY QDa performance mass spectrometer. The gradient profile is as shown in Table 2.

Table 2. Semi-preparative HPLC gradient profile.

\begin{tabular}{|l|l|l|l|l|}
\hline $\begin{array}{l}\text { Time } \\
(\text { mins })\end{array}$ & $\begin{array}{l}\text { Flow } \\
(\mathrm{mL} / \mathrm{min})\end{array}$ & $\begin{array}{l}\% \mathrm{H}_{2} \mathrm{O}+ \\
0.1 \% \mathrm{TFA}\end{array}$ & $\begin{array}{l}\% \mathrm{MeOH}+ \\
0.1 \% \mathrm{TFA}\end{array}$ & Curve \\
\hline 0 & 20 & 95 & 5 & 6 \\
\hline 1 & 20 & 95 & 5 & 6 \\
\hline 17 & 20 & 5 & 95 & 6 \\
\hline 18 & 20 & 5 & 95 & 6 \\
\hline 20 & 20 & 95 & 5 & 6 \\
\hline
\end{tabular}

Purity of all novel compounds except NI-Pano was determined using analytical high-performance liquid chromatography (HPLC) on a PerkinElmer Flexar system with a Binary LC Pump and UV/Vis LC Detector. All biologically tested compounds were of $>95 \%$ purity as determined by HPLC. For determination of compound purity on reversed phase (RP) 2-10 $\mu \mathrm{L}$ of sample was injected a Dionex Acclaim 120 column $(\mathrm{C} 18,5 \mu \mathrm{m}, 12 \AA, 4.6 \times 150 \mathrm{~mm})$. The gradient profile, unless otherwise stated is shown in Table 3. Method A refers to the solvents shown without modifiers. Method B refers to the solvents shown with the addition of $0.1 \% \mathrm{v} / \mathrm{V}$ TFA. Method C refers to the solvents shown, without modifiers, with an additional 10-minute hold at $5 \% \mathrm{H}_{2} \mathrm{O}, 95 \% \mathrm{MeCN}$ at the end of the gradient profile.

Table 3. Analytical HPLC gradient profile for Methods A, B and C.

\begin{tabular}{|l|l|l|l|}
\hline Time $(\mathrm{min})$ & Flow $(\mathrm{mL} / \mathrm{min})$ & $\% \mathrm{H}_{2} \mathrm{O}$ & $\% \mathrm{MeCN}$ \\
\hline 0 & 1.5 & 95 & 5 \\
\hline 10 & 1.5 & 5 & 95 \\
\hline 15 & 1.5 & 5 & 95 \\
\hline
\end{tabular}

Purity of NI-Pano was determined using analytical HPLC as described above (Method B) or by one of the methods described below. Method D: Purity was determined using analytical HPLC on an Agilent 1260 Infinity II fitted with a quaternary pump, vial sam- pler, DADWR, column chamber and an Agilent Infinity fraction collector fitted with a XBridge BEH C18, $4.6 \times 150 \mathrm{~mm}, 5 \mu \mathrm{m}$ column. Samples were prepared in $10 \%$ DMSO in $\mathrm{MeOH}$ and injected at $10 \mu \mathrm{L}$. The gradient profile is shown in Table 4.

Table 4. Gradient profile for Agilent Infinity.

\begin{tabular}{|l|l|l|l|}
\hline $\begin{array}{l}\text { Time } \\
(\text { mins })\end{array}$ & $\begin{array}{l}\text { Flow } \\
(\mathrm{mL} / \mathrm{min})\end{array}$ & $\begin{array}{l}\% \mathrm{H}_{2} \mathrm{O}+0.1 \% \\
\text { TFA }\end{array}$ & $\begin{array}{l}\% \text { MeCN } \\
0.1 \% \text { TFA }\end{array}$ \\
\hline 0 & 1 & 95 & 5 \\
\hline 1 & 1 & 95 & 5 \\
\hline 11 & 1 & 5 & 95 \\
\hline 13 & 1 & 5 & 95 \\
\hline 14 & 1 & 95 & 5 \\
\hline 15 & 1 & 95 & 5 \\
\hline
\end{tabular}

Method E: Purity was determined using analytical HPLC on a Waters 2695 autosampler with Waters QDa detector fitted with an ACE Excel 3 C18 Amide column $(100 \times 3 \mathrm{~mm}, 3 \mu \mathrm{m})$. Samples were prepared at $10 \mu \mathrm{M}$ in $0.1 \%$ DMSO in $\mathrm{H}_{2} \mathrm{O}$ and injected at $10 \mu \mathrm{L}$. Samples were run on an isocratic method $\mathrm{H}_{2} \mathrm{O}+0.1 \%$ TFA/Methanol + $0.1 \%$ TFA $(70: 30)$ at $3 \mathrm{~mL} / \mathrm{min}$ at $35^{\circ} \mathrm{C}$.

Experimental methods

2-Methyltryptamine $(\mathbf{S 2})^{77}$

5-Chloropentan-1-one (S1) (3.55 mL, $27.4 \mathrm{mmol}, 1.4 \mathrm{eq}, 85 \%$ purity) was added dropwise to a rapidly stirred solution of phenylhydrazine $(2.00 \mathrm{~mL}$, $19.6 \mathrm{mmol}, 1.0 \mathrm{eq})$ in absolute ethanol $(200 \mathrm{~mL})$ at rt. The solution was then slowly heated to $80^{\circ} \mathrm{C}$ (WARNING: uncontrolled exotherm can occur if heated too fast) and stirred at this temperature for $18 \mathrm{~h}$, cooled to rt and concentrated in vacuo. The residue was partitioned between water $(100 \mathrm{~mL})$ and dichloromethane $(100 \mathrm{~mL})$, the aqueous layer was separated and extracted with dichloromethane $(2 \times 100 \mathrm{~mL})$. A saturated aqueous solution of sodium hydrogen carbonate $(20 \mathrm{~mL})$ was added to the aqueous components, which were then extracted with dichloromethane $(2 \times 100 \mathrm{~mL})$. A $2 \mathrm{M}$ aqueous solution of sodium hydroxide $(20 \mathrm{~mL})$ was added to the aqueous components, which were then extracted with ethyl acetate $(3 \times 50 \mathrm{~mL})$. The ethyl acetate components were then washed with water $(100 \mathrm{~mL})$, brine $(100 \mathrm{~mL})$, dried $\left(\mathrm{Na}_{2} \mathrm{SO}_{4}\right)$, filtered, and concentrated in vacuo to yield the title compound (S2) $(3.02 \mathrm{~g}, 89 \%)$ as a yellow solid. $R$ $0.29\left(10 \% \mathrm{MeOH} / \mathrm{CH}_{2} \mathrm{Cl}_{2}+1 \% \mathrm{Et}_{3} \mathrm{~N}\right) ; \mathrm{mp} 91-93^{\circ} \mathrm{C}$ (from methanol) [lit., ${ }^{77} 95^{\circ} \mathrm{C}$ ] [lit., ${ }^{64} 90^{\circ} \mathrm{C}$ from toluene]; ${ }^{1} \mathrm{H}$ NMR $\left(400 \mathrm{MHz}, \mathrm{CDCl}_{3}\right) \delta_{\mathrm{H}}$ 8.20 (1H, br. s), 7.51 (1 H, dd, J 7.0, 1.5), 7.29-7.21 (1H, m), 7.17-7.04 $(2 \mathrm{H}, \mathrm{m}), 2.98(2 \mathrm{H}, \mathrm{td}, J 6.7,0.7), 2.86(2 \mathrm{H}, \mathrm{t}, J 6.7), 2.37$ (3H, s); LRMS $\mathrm{m} / z\left(\mathrm{ESI}^{+}\right) 277(38 \%), 175\left(100 \%,[\mathrm{M}+\mathrm{H}]^{+}\right), 158\left(68 \%,\left[\mathrm{M}-\mathrm{NH}_{2}\right]^{+}\right)$. The spectroscopic data are consistent with literature. ${ }^{77}$

(E)-Methyl-3-(4-formylphenyl)prop-2-enoate (S4) $)^{78}$

Methyl acrylate $(387 \mu \mathrm{L}, 4.32 \mathrm{mmol}, 4.0 \mathrm{eq})$ was added to a solution of 4 bromobenzaldehyde (S3) (200 mg, $1.08 \mathrm{mmol}, 1.0 \mathrm{eq}$ ), palladium(II) acetate $(12.0 \mathrm{mg}, 0.0533 \mathrm{mmol}, 0.05 \mathrm{eq})$ and potassium acetate $(212 \mathrm{mg}$, $2.16 \mathrm{mmol}, 2.0 \mathrm{eq})$ in $N, N$-dimethylformamide $(11 \mathrm{~mL})$ and heated to $110^{\circ} \mathrm{C}$ for $24 \mathrm{~h}$. The reaction was cooled to rt and diluted with diethyl ether $(110 \mathrm{~mL})$ then filtered through a plug of silica and concentrated in vacuo to yield the title compound (S4) (203 mg, 99\%) as a colorless solid. $R_{f} 0.58$ (50\% ethyl acetate/petroleum ether); $\mathrm{mp} 84-86^{\circ} \mathrm{C}$ (from EtOH), [lit. ${ }^{78} 81-$ $84^{\circ} \mathrm{C}$ from EtOH]; ${ }^{1} \mathrm{H}$ NMR $\left(400 \mathrm{MHz}, \mathrm{CDCl}_{3}\right) \delta_{\mathrm{H}} 10.02(1 \mathrm{H}, \mathrm{s}), 7.89$ $(2 \mathrm{H}, \mathrm{d}, J 8.0), 7.71(1 \mathrm{H}, \mathrm{d}, J 16.1), 7.66(2 \mathrm{H}, \mathrm{d}, J 8.0), 6.54(1 \mathrm{H}, \mathrm{d}, J 16.1)$, $3.82(3 \mathrm{H}, \mathrm{s})$; LRMS $\left(\mathrm{ESI}^{+}\right) 381\left([2 \mathrm{M}+\mathrm{H}]^{+}, 100 \%\right), 205(61 \%), 108(76 \%)$. The spectroscopic data are consistent with literature. ${ }^{78}$ 
(E)-Methyl-3-(4-[(2-[2-methyl-1 H-indol-3-yl] ethylamino)methyl $]$ phenyl)prop-2-enoate (16)

(E)-Methyl-3-(4-formylphenyl)prop-2-enoate (S4) (322 mg, $1.70 \mathrm{mmol}$, 1.0 eq), 2-methyltryptamine (S2) (590 mg, 3.39 mmol, 2.0 eq) and 3 Å molecular sieves $(1.00 \mathrm{~g})$ were combined in a solution of 1,2-dichloroethane $(21 \mathrm{~mL})$ and acetic acid $(100 \mu \mathrm{L}, 1.70 \mathrm{mmol}, 1.0 \mathrm{eq}$ ) (on scales $>1.0 \mathrm{~g}, 2.0$ eq of acetic acid was required to maintain the yield) and stirred at $\mathrm{rt}$ for $1 \mathrm{~h}$. Sodium triacetoxyborohydride $(719 \mathrm{mg}, 3.39 \mathrm{mmol}, 2.0 \mathrm{eq})$ was added to the solution and stirred for $18 \mathrm{~h}$. The reaction mixture was filtered through a pad of Celite then quenched with saturated aqueous sodium hydrogen carbonate solution $(50 \mathrm{~mL})$ and extracted with chloroform $(2 \times 100 \mathrm{~mL})$. The organic components were combined and washed with water $(200 \mathrm{~mL})$, brine $(200 \mathrm{~mL})$ then dried $\left(\mathrm{Na}_{2} \mathrm{SO}_{4}\right)$, filtered, and concentrated in vacuo. Purification using column chromatography (elution with 3-70\% ethanol:chloroform) yielded the title compound (16) $(509 \mathrm{mg}, 86 \%)$ as a colorless solid. $R_{f} 0.32\left(10 \% \mathrm{EtOH} / \mathrm{CHCl}_{3}\right) ; \mathrm{mp} 82-84^{\circ} \mathrm{C}$ (from dichloromethane/hexane); $\bar{v}_{\max }$ (thin film) $/ \mathrm{cm}^{-1} 3401,3055,2918,2851,1718$, $1608,1462,1434,1325,1206,1170 ;{ }^{1} \mathrm{H}$ NMR $\left(400 \mathrm{MHz}, \mathrm{CDCl}_{3}\right) \delta_{\mathrm{H}} 7.91$ $(1 \mathrm{H}, \mathrm{s}), 7.67(1 \mathrm{H}, \mathrm{d}, J 16.1), 7.51(1 \mathrm{H}, \mathrm{d}, J 7.7), 7.44(2 \mathrm{H}, \mathrm{d}, J 8.2), 7.28(2 \mathrm{H}$, d, J8.2), 7.26-7.24 (1H, m), 7.15-7.05 (2H, m), $6.41(1 \mathrm{H}, \mathrm{d}, J 16.1), 3.81$ $(5 \mathrm{H}, \mathrm{s}), 2.99-2.88(4 \mathrm{H}, \mathrm{m}), 2.37(3 \mathrm{H}, \mathrm{s}) ;{ }^{13} \mathrm{C} \mathrm{NMR}\left(101 \mathrm{MHz} \mathrm{CDCl}_{3}\right) \delta_{\mathrm{c}}$ 167.7, 144.8, 143.1, 135.4, 133.1, 131.8, 128.8, 128.6, 128.2, 121.1, 119.3, 118.1, 117.3, 110.3, 109.3, 53.6, 51.8, 49.7, 24.9, 11.9; HRMS m/z $\left(\mathrm{ESI}^{+}\right)$ Found: 349.1907, $\mathrm{C}_{22} \mathrm{H}_{25} \mathrm{~N}_{2} \mathrm{O}_{2}$ requires $[\mathrm{M}+\mathrm{H}]^{+} 349.1911$; LRMS $\left(\mathrm{ESI}^{+}\right)$ $349\left([\mathrm{M}+\mathrm{H}]^{+}, 100 \%\right), 332(7 \%), 158(9 \%)$; HPLC Method A, Retention time - $8.0 \mathrm{~min}, 97 \%$.

(E)- $N$-Hydroxy-3-(4-(((2-(2-methyl-1H-indol-3-yl)ethyl)amino)methyl)phenyl)acrylamide (panobinostat, 2$)^{61}$

A solution of potassium hydroxide $(2.8 \mathrm{~g}, 50 \mathrm{mmol}, 168 \mathrm{eq})$ in dry methanol $(7 \mathrm{~mL})$ was added dropwise with rapid stirring to a solution of hydroxylamine hydrochloride $(2.3 \mathrm{~g}, 34 \mathrm{mmol}, 114 \mathrm{eq})$, in dry methanol $(12 \mathrm{~mL})$. The precipitate was quickly removed by filtration and the resulting solution was added to a solution of $16(0.10 \mathrm{~g}, 0.30 \mathrm{mmol}, 1.0 \mathrm{eq})$ in dry methanol $(1 \mathrm{~mL})$. The reaction mixture was stirred at $\mathrm{rt}$ for $20 \mathrm{~h}$ then quenched to $\mathrm{pH}$ 7 with $1 \mathrm{M}$ aqueous hydrochloric acid then extracted with ethyl acetate $(3 \times 50 \mathrm{~mL})$. The organic components were washed with brine $(150 \mathrm{~mL})$, dried $\left(\mathrm{Na}_{2} \mathrm{SO}_{4}\right)$, filtered, and concentrated in vacuo. Purification using column chromatography (elution with 1:2:3 water:ethanol:ethyl acetate) yielded the title compound (2) (63 mg, 63\%) as a colorless solid. $R_{f} 0.54$ (1:2:3 water:isopropanol:ethyl acetate); $\mathrm{mp} 100-104{ }^{\circ} \mathrm{C}$ (from methanol) [lit., ${ }^{79} 109-115^{\circ} \mathrm{C}$ ]; $\bar{v}_{\max }$ (thin film) $/ \mathrm{cm}^{-1} 3195,3055,2921,1659,1623$, $1462,1340,1049,977 ;{ }^{1} \mathrm{H}$ NMR $\left(500 \mathrm{MHz}, \mathrm{CD}_{3} \mathrm{OD}\right) \delta_{\mathrm{H}} 7.54(2 \mathrm{H}, \mathrm{d}, J$ 15.8), 7.49 (2H, d, J7.9), $7.38(1 \mathrm{H}, \mathrm{d}, J 7.9), 7.29(2 \mathrm{H}, \mathrm{d}, J 7.9), 7.23(1 \mathrm{H}$, d, J8.1), 7.00 (1H, ddd, J8.1, 7.0, 1.2), 6.92 (1H, ddd, J7.9, 7.0, 1.0), 6.45 $(1 \mathrm{H}, \mathrm{d}, J 15.8), 3.83(2 \mathrm{H}, \mathrm{s}), 2.95(2 \mathrm{H}, \mathrm{t}, J 7.2), 2.87(2 \mathrm{H}, \mathrm{t}, J 7.2), 2.35(3 \mathrm{H}$, s); ${ }^{13} \mathrm{C}$ NMR $\left(126 \mathrm{MHz}, \mathrm{CD}_{3} \mathrm{OD}\right) \delta_{\mathrm{C}} 166.3,141.4,141.1,137.2,135.5$, 133.2, 130.2, 129.8, 128.9, 121.4, 119.5, 118.5, 118.3, 111.4, 108.4, 53.6, 50.1, 24.6, 11.4; HRMS $m / z\left(\mathrm{ESI}^{+}\right)$Found 350.18630, $\mathrm{C}_{21} \mathrm{H}_{24} \mathrm{O}_{2} \mathrm{~N}_{3}$ requires $[\mathrm{M}+\mathrm{H}]^{+}$350.18625; LRMS $\left(\mathrm{ESI}^{+}\right) 350([\mathrm{M}+\mathrm{H}]+, 100 \%), 333(10 \%), 242$ (8\%), 158 (40\%); HPLC Method B, Retention time - $6.5 \mathrm{~min}, 94-99 \% \mathrm{pu}-$ rity at three wavelengths, $97 \%$ mean. All batches used for biological assays were $>95 \%$ purity.

$N$-Phthalimido- $O$-(4'-nitrobenzyl)-hydroxylamine (4) ${ }^{80}$

$N, N$-Diisopropylethylamine $(5.78 \mathrm{~mL}, 33.1 \mathrm{mmol}, 1.8 \mathrm{eq})$ was added to a stirred solution of $N$-hydroxyphthalimide $(3.00 \mathrm{~g}, 18.4 \mathrm{mmol}, 1.0 \mathrm{eq})$ in $N, N$-dimethylformamide ( $18 \mathrm{~mL})$. 4-Nitrobenzyl chloride (3) $(4.12 \mathrm{~g}$, $23.9 \mathrm{mmol}, 1.3 \mathrm{eq})$ was added the solution was heated to $70^{\circ} \mathrm{C}$ for $2 \mathrm{~h}$. The reaction was cooled to rt, diluted with ethyl acetate $(200 \mathrm{~mL})$ and washed with aqueous $0.5 \mathrm{M}$ lithium chloride $(4 \times 200 \mathrm{~mL})$, dried $\left(\mathrm{MgSO}_{4}\right)$, filtered, and concentrated in vacuothen crystallized from hot ethanol to yield the title compound (4) $(4.61 \mathrm{~g}, 84 \%)$ as a colorless solid. $R_{f} 0.12$ (20\% ethyl acetate: petroleum ether); mp $191-193{ }^{\circ} \mathrm{C}$ (from EtOH) [lit., ${ }^{80} 191-193{ }^{\circ} \mathrm{C}$ ]; ${ }^{1} \mathrm{H}$ $\operatorname{NMR}\left(400 \mathrm{MHz}, \mathrm{CDCl}_{3}\right) \delta_{\mathrm{H}} 8.30-8.21(2 \mathrm{H}, \mathrm{m}), 7.87-7.80(2 \mathrm{H}, \mathrm{m}), 7.79$ $7.76(2 \mathrm{H}, \mathrm{m}), 7.76-7.72(2 \mathrm{H}, \mathrm{m}), 5.31(2 \mathrm{H}, \mathrm{s}) ; \mathrm{LRMS} \mathrm{m} / z\left(\mathrm{ESI}^{+}\right) 321$ $\left(100 \%,[\mathrm{M}+\mathrm{Na}]^{+}\right)$. The spectroscopic data are consistent with literature. ${ }^{80}$
$O$-(4-Nitrobenzyl)-hydroxylamine $(\mathbf{5})^{80}$

A $65 \% \mathrm{w} / \mathrm{V}$ aqueous solution of hydrazine monohydrate $(501 \mu \mathrm{L}$, $6.71 \mathrm{mmol}, 4.0 \mathrm{eq}$ ) was added to a solution of $\mathrm{N}$-phthalimido- $\mathrm{O}$-(4-nitrobenzyl)-hydroxylamine (4) $(500 \mathrm{mg}, 1.68 \mathrm{mmol}, 1.0 \mathrm{eq})$ in methanol $(9 \mathrm{~mL})$ and dichloromethane $(9 \mathrm{~mL})$, and stirred at $\mathrm{rt}$ for $4 \mathrm{~h}$. The suspension was diluted with dichloromethane $(20 \mathrm{~mL})$, filtered, and concentrated in vacuo. The residue was dissolved in diethyl ether $(40 \mathrm{~mL})$, washed with water $(2 \times 40 \mathrm{~mL})$ then brine $(40 \mathrm{~mL})$, dried $\left(\mathrm{Na}_{2} \mathrm{SO}_{4}\right)$, filtered, and concentrated in vacuo. The residue was dried by azeotroping from toluene, the title compound (5) (202 mg, 72\%) crystallized on cooling to give a yellow solid. $R_{f} 0.44$ ( $100 \%$ ethyl acetate); $\mathrm{mp} 47-50^{\circ} \mathrm{C}$ (from dichloromethane:hexane) [lit., ${ }^{81} 56^{\circ} \mathrm{C}$ from light petroleum], [lit., $\left.{ }^{82} 38-40{ }^{\circ} \mathrm{C}\right] ;{ }^{1} \mathrm{H}$ $\operatorname{NMR}\left(400 \mathrm{MHz}, \mathrm{CDCl}_{3}\right) \delta_{\mathrm{H}} 8.53-8.02(2 \mathrm{H}, \mathrm{m}), 7.59-7.40(2 \mathrm{H}, \mathrm{m}), 5.53$ (2H, br s), 4.77 (2H, s).; LRMS m/z (ESI $\left.{ }^{+}\right) 393$ (60\%), 209 (100\%), 152 $\left([\mathrm{M}-\mathrm{NH} 2]^{+}, 42 \%\right)$. The spectroscopic data are consistent with literature. ${ }^{80}$

(5-Nitrothiophen-2-yl)methanol (S5) ${ }^{83-84}$

Sodium borohydride $(0.484 \mathrm{~g}, 12.7 \mathrm{mmol}, 2.0 \mathrm{eq})$ was added portion-wise to a stirred solution of 2-formyl-5-nitrothiophene (6) $(1.00 \mathrm{~g}, 6.37 \mathrm{mmol}$, $1.0 \mathrm{eq})$ in methanol $(64 \mathrm{~mL})$ at $0{ }^{\circ} \mathrm{C}$. The reaction mixture was warmed to $\mathrm{rt}$ over $2 \mathrm{~h}$. After this time, it was cooled to $0^{\circ} \mathrm{C}$ and the $\mathrm{pH}$ carefully adjusted to $\mathrm{pH} 7$ with a $1 \mathrm{M}$ aqueous solution of hydrochloric acid. The solution was diluted with methanol $(30 \mathrm{~mL})$ and concentrated in vacuo. Purification using column chromatography (10-60\% ethyl acetate:petroleum ether) yielded the title compound (S5) $(1.00 \mathrm{~g}, 99 \%)$ as a pale yellow oil. $R f 0.48$ (50\% ethyl acetate:petroleum ether); ${ }^{1} \mathrm{H}$ NMR $\left(400 \mathrm{MHz}, \mathrm{CDCl}_{3}\right) \delta_{\mathrm{H}} 7.82$ $(1 \mathrm{H}, \mathrm{d}, J 4.1), 6.94(1 \mathrm{H}, \mathrm{dt}, J 4.1,1.0), 4.88(2 \mathrm{H}, \mathrm{br} \mathrm{s}), 2.18(1 \mathrm{H}, \mathrm{t}, J 5.6)$; LRMS $m / z\left(\mathrm{ESI}^{-}\right) 687$ (67\%), 659 (39\%), 643 (74\%), 320 (34\%), 275 (37\%), 643 (74\%), $204(57 \%), 158\left([\mathrm{M}-\mathrm{H}]^{-}, 100 \%\right)$. The spectroscopic data are consistent with literature. ${ }^{83-84}$

(5-Nitrothiophen-2-yl)methyl bromide (7) ${ }^{85}$

Phosphorus tribromide $(1.41 \mathrm{~mL}, 12.3 \mathrm{mmol}, 2.0 \mathrm{eq})$ was added dropwise to a solution of (5-nitrothiophen-2-yl)methanol (S5) $(979 \mathrm{mg}, 6.16 \mathrm{mmol}$, $1.0 \mathrm{eq})$ in dichloromethane $(123 \mathrm{~mL})$ at $0{ }^{\circ} \mathrm{C}$. The solution was warmed to rt over $5 \mathrm{~h}$, quenched with a saturated aqueous solution of sodium hydrogen carbonate $(50 \mathrm{~mL})$, and extracted with dichloromethane $(100 \mathrm{~mL})$. The organic components were washed with brine $(100 \mathrm{~mL})$, dried $\left(\mathrm{Na}_{2} \mathrm{SO}_{4}\right)$, filtered, and concentrated in vacuo. Purification by filtration through a pad of silica gel (elution with 4:1 petroleum ether:ethyl acetate) yielded the title compound (7) (652 mg, 48\%) as a brown oil. Rf0.53 (20\% ethyl acetate:petroleum ether); $\bar{v}_{\max }$ (thin film) $/ \mathrm{cm}^{-1} 3106(\mathrm{CH}), 1496\left(\mathrm{NO}_{2}\right), 1332\left(\mathrm{NO}_{2}\right)$, $1237,1212,1028 ;{ }^{1} \mathrm{H}$ NMR $\left(500 \mathrm{MHz}, \mathrm{CDCl}_{3}\right) \delta_{\mathrm{H}} 7.78(1 \mathrm{H}, \mathrm{d}, J 4.2), 7.06$ $(1 \mathrm{H}, \mathrm{dt}, J 4.2,0.7), 4.62(2 \mathrm{H}, \mathrm{d}, J 0.7) ;{ }^{13} \mathrm{C} \mathrm{NMR}\left(126 \mathrm{MHz}, \mathrm{CDCl}_{3}\right) \delta \mathrm{c}$ $152.0^{*}, 148.4,128.5,127.2,24.7$; HRMS $m / z\left(\mathrm{EI}^{+}\right)$Found: 220.9151, $\mathrm{C}_{5} \mathrm{H}_{4} \mathrm{BrNO}_{2} \mathrm{~S}$ requires $[\mathrm{M}]^{+}$220.9141; LRMS No ion observed; HPLC Method B, Retention time - $9.6 \mathrm{~min}, 94 \%$. ${ }^{*}$ Signal at 152.0 confirmed by ${ }^{1} \mathrm{H}-$ ${ }^{13} \mathrm{C}$ HMBC correlation see SI for details. The spectroscopic data are consistent with literature. ${ }^{85}$

$N$-Phthalimido- $O$-(5-nitrothiophen-2-yl)-hydroxylamine (S6)

A solution of $N$-hydroxyphthalimide (388 $\mathrm{mg}, 2.38 \mathrm{mmol}, 1.1 \mathrm{eq}$ ) in $N, N$ dimethylformamide $(1.1 \mathrm{~mL})$ was added to a solution of (5-nitrothiophen2-yl)methyl bromide (7) $(480 \mathrm{mg}, 2.16 \mathrm{mmol}, 1.0 \mathrm{eq})$ in $N, N$-dimethylformamide $(1.1 \mathrm{~mL})$ and stirred at $\mathrm{rt}$ for $2 \mathrm{~h}$. The reaction mixture was diluted with ethyl acetate $(20 \mathrm{~mL})$, quenched to $\mathrm{pH} 7$ with a $1 \mathrm{M}$ aqueous solution of hydrochloric acid then extracted with ethyl acetate $(3 \times 20 \mathrm{~mL})$. The organic components were washed with a $0.5 \mathrm{M}$ aqueous solution of lithium chloride $(5 \times 20 \mathrm{~mL})$, brine $(20 \mathrm{~mL})$, dried $\left(\mathrm{MgSO}_{4}\right)$, filtered, and concentrated in vacuo. Purification using column chromatography (elution with 0 $5 \%$ ethanol:chloroform) removed some impurities. Trituration with ice cold chloroform yielded the title compound (S6) (413 mg, 63\%) as a tan solid. $R_{f}$ 0.54 ( $100 \%$ chloroform); mp $185-187^{\circ} \mathrm{C}$ (from chloroform); $\bar{\nu}_{\max }$ (thin film) $/ \mathrm{cm}^{-1} 1733,1503,1350 ;{ }^{1} \mathrm{H} \mathrm{NMR}\left(500 \mathrm{MHz}, \mathrm{CDCl}_{3}\right) \delta_{\mathrm{H}} 7.84(2 \mathrm{H}, \mathrm{dd}$, $J 5.5,3.1), 7.82(1 \mathrm{H}, \mathrm{d}, J 4.1), 7.78$ (2H, dd, J5.5, 3.1), 7.18 (1H, d, J4.1), $5.34(2 \mathrm{H}, \mathrm{s}) ;{ }^{13} \mathrm{C}$ NMR $\left(126 \mathrm{MHz}, \mathrm{CDCl}_{3}\right) \delta_{\mathrm{C}} 163.4,153.4,143.1,135.0$, 
$128.9,128.8,128.3,124.0,73.2$; HRMS No ion observed; LRMS No ion observed; HPLC Method A, Retention time - 9.5 min, 97\%.

$O$-(5-Nitrothiophen-2-yl)methylene)hydroxylamine (8)

A $65 \% \mathrm{w} / \mathrm{V}$ aqueous solution of hydrazine monohydrate $(0.21 \mathrm{~mL}$, $2.6 \mathrm{mmol}, 4.0 \mathrm{eq}$ ), was added to a solution of $\mathrm{N}$-phthalimido- $\mathrm{O}$-(5-nitrothiophen-2-yl)-hydroxylamine (S6) $(0.20 \mathrm{~g}, 0.66 \mathrm{mmol}, 1.0 \mathrm{eq})$ in dichloromethane $(13 \mathrm{~mL})$ and stirred for $2 \mathrm{~h}$ at $\mathrm{rt}$. The resulting suspension was filtered through a pad of silica gel, eluting with chloroform, and concentrated in vacuo to yield the title compound (8) $(77 \mathrm{mg}, 68 \%)$ as an orange solid that decomposed rapidly. $R_{f} 0.34$ ( $100 \%$ chloroform); mp $40-42^{\circ} \mathrm{C}$ (from dichloromethane); $\bar{v}_{\max }$ (thin film) $/ \mathrm{cm}^{-1} 3322,3106,2920,1537,1497$, 1334,$1153 ;{ }^{1} \mathrm{H}$ NMR $\left(500 \mathrm{MHz}, \mathrm{CDCl}_{3}\right) \delta_{\mathrm{H}} 7.81(1 \mathrm{H}, \mathrm{d}, J 4.1), 6.96(1 \mathrm{H}$, dd, $J 4.1,0.9), 5.63(2 \mathrm{H}, \mathrm{s}), 4.80(2 \mathrm{H}, \mathrm{d}, J 0.9) ;{ }^{13} \mathrm{C}$ NMR $(126 \mathrm{MHz}$, $\left.\mathrm{CDCl}_{3}\right) \delta_{\mathrm{C}} 151.9,149.2,128.4,125.7,72.1$; HRMS No ion observed; LRMS No ion observed; HPLC Method A, Retention time - $6.8 \mathrm{~min}, 97 \%$.

5-Iodo-6-nitroquinoline $(\mathbf{1 0})^{86}$

5-Amino-6-nitroquinoline (9) (500 mg, $2.65 \mathrm{mmol}, 1.0 \mathrm{eq})$, copper(I) iodide $(503 \mathrm{mg}, 2.65 \mathrm{mmol}, 1.0 \mathrm{eq})$ and sodium nitrite $(402 \mathrm{mg}, 5.82 \mathrm{mmol}$, $2.2 \mathrm{eq})$ were combined and dissolved in dimethyl sulfoxide $(26 \mathrm{~mL})$ then heated to $60^{\circ} \mathrm{C}$. A $50 \%$ aqueous solution of hydroiodic acid $(2.20 \mathrm{~mL}$, $28.6 \mathrm{mmol}, 5.4 \mathrm{eq}$ ) was added dropwise at $60^{\circ} \mathrm{C}$ and heating was continued for $30 \mathrm{~min}$. The reaction mixture was cooled to $0{ }^{\circ} \mathrm{C}$ and quenched with a saturated aqueous solution of potassium carbonate. The quenched reaction mixture was extracted with ethyl acetate $(5 \times 50 \mathrm{~mL})$ and the combined organic fractions were washed with brine $(200 \mathrm{~mL})$, dried $\left(\mathrm{Na}_{2} \mathrm{SO}_{4}\right)$, filtered, and concentrated in vacuo. Purification using column chromatography, eluting with $0-100 \%$ ethyl acetate:petroleum ether, yielded the title compound (10) $(475 \mathrm{mg}, 60 \%)$ as an off-white solid. $R_{f} 0.53$ (50\% ethyl acetate:petroleum ether); mp $134-136{ }^{\circ} \mathrm{C}$ (from chloroform), [lit., ${ }^{86} 160-162{ }^{\circ} \mathrm{C}$ ]; ${ }^{1} \mathrm{H}$ $\operatorname{NMR}\left(500 \mathrm{MHz}, \mathrm{CDCl}_{3}\right) \delta_{\mathrm{H}} 9.02(1 \mathrm{H}, \mathrm{dd}, J 4.2,1.6), 8.68(1 \mathrm{H}, \mathrm{ddd}, J 8.7$, 1.6, 0.8), $8.22(1 \mathrm{H}, \mathrm{dd}, J 9.0,0.8), 7.94(1 \mathrm{H}, \mathrm{d}, J 9.0), 7.63(1 \mathrm{H}, \mathrm{dd}, J 8.7$, 4.2); LRMS $m / z\left(\mathrm{ESI}^{+}\right) 301$ ([M+H] $\left.]^{+}, 23 \%\right), 190(64 \%), 181$ (100\%), 144 $(29 \%)$. The spectroscopic data are consistent with literature. ${ }^{86}$

5-(Hydroxymethyl)-6-nitroquinoline $(\mathbf{S 7})^{57}$

5-Iodo-6-nitroquinoline $(\mathbf{1 0})(0.15 \mathrm{~g}, 0.50 \mathrm{mmol}, 1.0 \mathrm{eq})$ was dissolved in dry tetrahydrofuran $(2.5 \mathrm{~mL})$ and cooled to $-40^{\circ} \mathrm{C}$. A $1 \mathrm{M}$ solution of phenyl magnesium chloride $(0.55 \mathrm{~mL}, 0.55 \mathrm{mmol}, 1.1 \mathrm{eq})$ in 2-methyltetrahydrofuran was added dropwise and the solution was stirred for $10 \mathrm{~min}$. Paraformaldehyde $(60 \mathrm{mg}, 2.0 \mathrm{mmol}, 4.0 \mathrm{eq})$ was added to the solution and the reaction mixture was warmed to rt over $1 \mathrm{~h}$ then heated to $40^{\circ} \mathrm{C}$ for $18 \mathrm{~h}$. The reaction mixture was cooled to $\mathrm{rt}$, quenched with water $(20 \mathrm{~mL})$ and extracted with ethyl acetate $(3 \times 20 \mathrm{~mL})$. The combined organic fractions were washed with brine $(50 \mathrm{~mL})$, dried $\left(\mathrm{Na}_{2} \mathrm{SO}_{4}\right)$, filtered, and concentrated in vacuo. Purification by column chromatography, eluting with $0-100 \%$ ethyl acetate:petroleum ether, yielded the title compound (S7) $(88 \mathrm{mg}$, $86 \%)$ as an off-white solid. $R_{f} 0.30$ (ethyl acetate); mp $139-141{ }^{\circ} \mathrm{C}$ (from ethyl acetate); ${ }^{1} \mathrm{H}$ NMR $\left(400 \mathrm{MHz}, \mathrm{CDCl}_{3}\right) \delta_{\mathrm{H}} 9.09(1 \mathrm{H}, \mathrm{dd}, J 4.2,1.6), 8.78$ (1H, ddd, J8.7, 1.6, 0.9), 8.22 (1H, dd, J9.2, 0.9), $8.10(1 \mathrm{H}, \mathrm{d}, J 9.2), 7.65$ $(1 \mathrm{H}, \mathrm{dd}, J 8.7,4.2), 5.14(2 \mathrm{H}, \mathrm{s}), 2.79(1 \mathrm{H}, \mathrm{s}) ; \mathrm{LRMS} \mathrm{m} / z\left(\mathrm{ESI}^{+}\right) 205$ $\left([\mathrm{M}+\mathrm{H}]^{+}, 100 \%\right)$. The spectroscopic data are consistent with literature. ${ }^{57}$

\section{5-(Bromomethyl)-6-nitroquinoline (11) $)^{57}$}

5-(Hydroxymethyl)-6-nitroquinoline (S7) (63 mg, $0.31 \mathrm{mmol}, 1.0 \mathrm{eq}$ ) was dissolved in a $47 \%$ aqueous solution of hydrobromic acid $(0.62 \mathrm{~mL})$ and warmed to $75^{\circ} \mathrm{C}$ for $18 \mathrm{~h}$. The reaction mixture was cooled to rt and the $\mathrm{pH}$ was adjusted to 7 with solid potassium carbonate. The solution was extracted with ethyl acetate $(3 \times 20 \mathrm{~mL})$, dried $\left(\mathrm{Na}_{2} \mathrm{SO}_{4}\right)$, filtered, and concentrated in vacuo to yield the title compound (11) ( $82 \mathrm{mg}, 99 \%$ ) as a yellow solid. $R_{f}$ 0.37 (50\% ethyl acetate:petroleum ether), [lit., ${ }^{57} 0.33,50 \%$ ethyl acetate: petroleum ether]; mp $96-98^{\circ} \mathrm{C}$ (dec.; from chloroform), [lit., ${ }^{57} 112-114^{\circ} \mathrm{C}$ from ethyl acetate $] ;{ }^{1} \mathrm{H} \mathrm{NMR}\left(400 \mathrm{MHz}, \mathrm{CDCl}_{3}\right) \delta_{\mathrm{H}} 9.11(1 \mathrm{H}, \mathrm{dd}, J 4.2$, 1.6), 8.67 (1H, ddd, $J 8.7,1.6,0.9), 8.24(1 \mathrm{H}, \mathrm{d}, J 9.2), 8.14(1 \mathrm{H}, \mathrm{d}, J 9.2)$, $7.70(1 \mathrm{H}, \mathrm{dd}, J 8.7,4.2), 5.11(2 \mathrm{H}, \mathrm{s})$; LRMS $\mathrm{m} / z\left(\mathrm{ESI}^{+}\right) 407$ (100\%), 377 (29\%), $\left.269\left({ }^{81} \mathrm{Br}[\mathrm{M}+\mathrm{H}]\right]^{+}, 12 \%\right), 267\left({ }^{79} \mathrm{Br}[\mathrm{M}+\mathrm{H}]+, 11 \%\right), 221(16 \%)$. The spectroscopic data are consistent with literature. ${ }^{57}$
$N$-Phthalimido- $O$-(6-nitroquinolin-5-yl)-hydroxylamine (S8)

$N, N$-Diisopropylethylamine $(75 \mu \mathrm{L}, 0.43 \mathrm{mmol}, 1.4 \mathrm{eq})$ was added to a stirred solution of $N$-hydroxyphthalimide $(60 \mathrm{mg}, 0.37 \mathrm{mmol}, 1.2 \mathrm{eq})$ in $\mathrm{N}, \mathrm{N}$-dimethylformamide $(1 \mathrm{~mL})$. 6-Nitroquinolin-5-yl-methyl bromide (11) $(82 \mathrm{mg}, 0.31 \mathrm{mmol}, 1.0 \mathrm{eq})$ was added and the solution was stirred at $70^{\circ} \mathrm{C}$ for $2 \mathrm{~h}$. The reaction was cooled to rt, diluted with ethyl acetate $(20 \mathrm{~mL})$, washed with $0.5 \mathrm{M}$ lithium chloride solution $(4 \times 20 \mathrm{~mL})$ then dried $\left(\mathrm{Na}_{2} \mathrm{SO}_{4}\right)$, filtered, and concentrated in vacuo. Purification using column chromatography, eluting with $0-60 \%$ ethyl acetate:petroleum ether, then crystallisation from hot chloroform yielded the title compound (S8) ( $94 \mathrm{mg}, 88 \%)$ as a colorless solid. $R f 0.21$ (50\% ethyl acetate:petroleum ether); mp $225-227^{\circ} \mathrm{C}$ (dec.; from DMSO); $\bar{v}_{\max }$ (thin film) $/ \mathrm{cm}^{-1} 1721$, $1527,1392,1138 ;{ }^{1} \mathrm{H}$ NMR $\left(500 \mathrm{MHz},\left(\mathrm{D}_{6}\right.\right.$-DMSO) $\delta_{\mathrm{H}} 9.16(1 \mathrm{H}, \mathrm{dd}, J 4.1$, 1.6), 9.14-9.08 (1H, m), $8.30(1 \mathrm{H}, \mathrm{d}, J 9.1), 8.16(1 \mathrm{H}, \mathrm{d}, J 9.1), 7.97-7.77$ $(6 \mathrm{H}, \mathrm{m}), 5.81(2 \mathrm{H}, \mathrm{s}) ;{ }^{13} \mathrm{C}$ NMR $\left(126 \mathrm{MHz},\left(\mathrm{D}_{6}-\mathrm{DMSO}\right) \delta_{\mathrm{C}} 162.9,153.3\right.$, 148.7, 148.2, 135.1, 134.9, 132.9, 128.4, 127.4, 125.0, 123.44, 123.42, 123.3, 69.6; HRMS $m / z\left(\mathrm{ESI}^{+}\right)$Found: $350.07711, \mathrm{C}_{18} \mathrm{H}_{12} \mathrm{O}_{5} \mathrm{~N}_{3}$ requires $[\mathrm{M}+\mathrm{H}]^{+}$ 350.07715; LRMS $\mathrm{m} / z\left(\mathrm{ESI}^{+}\right) 372\left([\mathrm{M}+\mathrm{Na}]^{+}, 21 \%\right), 350\left([\mathrm{M}+\mathrm{H}]^{+}, 17 \%\right)$, 107 (100\%); HPLC Method A, Retention time - 9.1 min, 95\%.

O-(6-Nitroquinolin-5-yl)-hydroxylamine (12)

A $65 \% \mathrm{w} / \mathrm{v}$ aqueous solution of hydrazine monohydrate $(0.14 \mathrm{~mL}$, $1.9 \mathrm{mmol}, 8.0 \mathrm{eq})$ was added to a solution of $N$-phthalimido- $O$-(6-nitroquinolin-5-yl)-hydroxylamine (S8) ( $84 \mathrm{mg}, 0.24 \mathrm{mmol}, 1.0 \mathrm{eq})$ in dichloromethane $(3.2 \mathrm{~mL})$ and methanol $(1.2 \mathrm{~mL})$ and stirred at $\mathrm{rt}$ for $5 \mathrm{~h}$. The suspension was diluted with dichloromethane $(20 \mathrm{~mL})$, filtered then concentrated in vacuo. The residue was triturated with minimal chloroform to yield the title compound (12) (49 $\mathrm{mg}, 92 \%)$ as an orange solid that decomposed rapidly. $R_{f} 0.26$ (50\% ethyl acetate petroleum ether); $\mathrm{mp} 96-98^{\circ} \mathrm{C}$ (from chloroform); $\bar{v}_{\max }$ (thin film) $/ \mathrm{cm}^{-1} 1531,1499,1414,1008,904 ;{ }^{1} \mathrm{H}$ NMR $\left(500 \mathrm{MHz}, \mathrm{CDCl}_{3}\right) \delta_{\mathrm{H}} 9.06(1 \mathrm{H}, \mathrm{dd}, J 4.2,1.7), 8.71(1 \mathrm{H}, \mathrm{dd}, J 8.8,1.7), 8.21$ (1H, d, J9.1), $8.01(1 \mathrm{H}, \mathrm{d}, J 9.1), 7.60(1 \mathrm{H}, \mathrm{dd}, J 8.8,4.2), 5.51(2 \mathrm{H}, \mathrm{br} \mathrm{s})$, $5.33(2 \mathrm{H}, \mathrm{s}) ;{ }^{13} \mathrm{C}$ NMR $\left(126 \mathrm{MHz}, \mathrm{CDCl}_{3}\right) \delta_{\mathrm{C}} 152.8,149.1,149.0,134.8$, 132.0, 128.6, 127.6, 123.6, 122.9, 68.6.; HRMS $\mathrm{m} / z\left(\mathrm{ESI}^{+}\right)$Found: 220.07168, $\mathrm{C}_{10} \mathrm{H}_{10} \mathrm{O}_{3} \mathrm{~N}_{3}$ requires $[\mathrm{M}+\mathrm{H}]^{+}$220.07167; LRMS $\mathrm{m} / \mathrm{z}\left(\mathrm{ESI}^{-}\right)$ $256\left(\left[\mathrm{M}+{ }^{37} \mathrm{Cl}\right]^{-}, 26 \%\right), 254\left(\left[\mathrm{M}+{ }^{35} \mathrm{Cl}\right]^{-}, 100 \%\right), 218\left([\mathrm{M}-\mathrm{H}]^{-}, 93 \%\right), 216$ (59\%), 185 (29\%), 169 (46\%), 113 (37\%); HPLC Method A, Retention time - $6.6 \mathrm{~min}, 90 \%$.

Ethyl (2-amino-1-methyl-imidazol-5-yl)carboxylate (14) ${ }^{29,87-88}$

Ethyl $N$-methylglycine hydrochloride (13) $(6.00 \mathrm{~g}, 39.0 \mathrm{mmol}, 1.0 \mathrm{eq})$ was dried using lyophilization then suspended in a combination of dry tetrahydrofuran $(37 \mathrm{~mL})$, dry absolute ethanol $(4.2 \mathrm{~mL})$, and ethyl formate $(22 \mathrm{~mL})$ and cooled to $0^{\circ} \mathrm{C}$ under a stream of argon. Sodium hydride $(3.74 \mathrm{~g}, 156 \mathrm{mmol}, 4.0 \mathrm{eq})$ was added in small portions to the cooled suspension and, once gas evolution had ceased, the reaction mixture was warmed to $\mathrm{rt}$ and stirred for $18 \mathrm{~h}$. The reaction was quenched by the addition of wet diethyl ether $(200 \mathrm{~mL})$ and filtered. The collected solids were washed with diethyl ether $(2 \times 100 \mathrm{~mL})$ then dried under vacuum. The solids were then suspended in ethanol $(130 \mathrm{~mL})$, and concentrated hydrochloric acid $(26 \mathrm{~mL})$ was slowly added to the suspension. The suspension was stirred at $\mathrm{rt}$ for $2 \mathrm{~h}$ then filtered to remove salt. The resulting solution was concentrated in vacuo then dissolved in ethanol $(210 \mathrm{~mL})$ and water $(90 \mathrm{~mL})$, and the $\mathrm{pH}$ adjusted to 3 with aqueous $6 \mathrm{M}$ sodium hydroxide $(\sim 40 \mathrm{~mL})$. Cyanamide $(3.27 \mathrm{~g}, 77.9 \mathrm{mmol}, 2.0 \mathrm{eq})$ was added to the solution. The reaction solution was heated to $100^{\circ} \mathrm{C}$ for $2 \mathrm{~h}$, then cooled to rt and concentrated in vacuo. The residue was dissolved in ethyl acetate $(200 \mathrm{~mL})$, and saturated aqueous potassium carbonate solution $(100 \mathrm{~mL})$ was added. This mixture was extracted with ethyl acetate $(3 \times 100 \mathrm{~mL})$. The combined organic fractions were washed with brine $(300 \mathrm{~mL})$, dried $\left(\mathrm{Na}_{2} \mathrm{SO}_{4}\right)$, filtered, and concentrated in vacuo to yield the title compound (14) $(5.18 \mathrm{~g}, 79 \%)$ as a paleyellow solid which slowly decomposes at rt. Further purification or re-purification could be achieved by trituration with minimal chloroform but was usually unnecessary. $R_{f} 0.27$ (5\% ethanol: chloroform); mp $153-155^{\circ} \mathrm{C}$ (from methanol) [lit., ${ }^{88} 130-133^{\circ} \mathrm{C}$ (from water)]; ${ }^{1} \mathrm{H}$ NMR $(500 \mathrm{MHz}$, $\left.\mathrm{CDCl}_{3}\right) \delta_{\mathrm{H}} 7.44(1 \mathrm{H}, \mathrm{s}), 4.39(2 \mathrm{H}, \mathrm{br} \mathrm{s}), 4.26(2 \mathrm{H}, \mathrm{q}, J 7.1), 3.67(3 \mathrm{H}, \mathrm{s})$, 
$1.33(3 \mathrm{H}, \mathrm{t}, J 7.1)$; LRMS $\mathrm{m} / z\left(\mathrm{ESI}^{+}\right) 170\left([\mathrm{M}+\mathrm{H}]^{+}, 100 \%\right), 142(30 \%)$ The spectroscopic data are consistent with literature. ${ }^{29,88}$

Ethyl (1-methyl-2-nitro-imidazol-5-yl)carboxylate (S9) $29,87-88$

A solution of ethyl (2-amino-1-methyl-imidazol-5-yl)carboxylate (14) $(1.73 \mathrm{~g}, 10.2 \mathrm{mmol}, 1.0 \mathrm{eq})$ in glacial acetic acid $(18 \mathrm{~mL})$ was added, dropwise at $0{ }^{\circ} \mathrm{C}$, to a solution of sodium nitrite $(7.06 \mathrm{~g}, 102 \mathrm{mmol}, 10 \mathrm{eq})$ in water $(9 \mathrm{~mL})$. The solution was stirred at $0^{\circ} \mathrm{C}$ for $1 \mathrm{~h}$ then warmed to rt over $3 \mathrm{~h}$. The solution was extracted with dichloromethane $(3 \times 50 \mathrm{~mL})$. The combined organic fractions were washed with a saturated aqueous solution of sodium sulfite $(100 \mathrm{~mL})$, and brine $(100 \mathrm{~mL})$ then dried $\left(\mathrm{MgSO}_{4}\right)$, filtered, and concentrated in vacuo. The residue was dissolved in dichloromethane $(100 \mathrm{~mL})$ and filtered through a short pad of silica to yield the title compound (S9) (1.46 g, 72\%) as an off-white solid. $R_{f} 0.27$ (100\% dichloromethane); $\mathrm{mp} 51-53{ }^{\circ} \mathrm{C}$ (from dichloromethane) $\left[\right.$ lit., ${ }^{88} 56-58{ }^{\circ} \mathrm{C}$ (from dichloromethane)]; ${ }^{1} \mathrm{H}$ NMR $\left(400 \mathrm{MHz} \mathrm{CDCl}_{3}\right) \delta_{\mathrm{H}} 7.71(1 \mathrm{H}, \mathrm{s}), 4.37(2 \mathrm{H}$, q, J7.2), $4.32(3 \mathrm{H}, \mathrm{s}), 1.38(3 \mathrm{H}, \mathrm{t}, J 7.2)$; LRMS $\mathrm{m} / z\left(\mathrm{ESI}^{+}\right) 200\left([\mathrm{M}+\mathrm{H}]^{+}\right.$, $100 \%), 172(65 \%)$. The spectroscopic data are consistent with literature. ${ }^{29,}$

(1-Methyl-2-nitro-imidazol-5-yl)methanol (S10) ${ }^{29,87-88}$

A solution of sodium borohydride $(0.160 \mathrm{~g}, 4.22 \mathrm{mmol}, 3.0 \mathrm{eq})$ in dry ethanol $(5.3 \mathrm{~mL})$ was added dropwise to a solution of ethyl 1-methyl-2-nitroimidazole-5-carboxylate (S9) $(0.280 \mathrm{~g}, 1.41 \mathrm{mmol}, 1.0 \mathrm{eq})$ in dry tetrahydrofuran $(7.0 \mathrm{~mL})$ with vigorous stirring at $0{ }^{\circ} \mathrm{C}$. The reaction was stirred at $0{ }^{\circ} \mathrm{C}$ for $3 \mathrm{~h}$ then slowly added to a stirred mixture of diethyl ether $(100 \mathrm{~mL})$ and wet methanol $(100 \mathrm{~mL})$ at $0{ }^{\circ} \mathrm{C}$. The resulting solution was stirred at $0{ }^{\circ} \mathrm{C}$ for 30 min then gradually acidified to $\mathrm{pH} 5$ with aqueous $2 \mathrm{M}$ hydrochloric acid. The solution was concentrated in vacuo to give a mostly aqueous solution. The residue was then extracted with ethyl acetate $(5 \times 50 \mathrm{~mL})$, the combined organic components were dried $\left(\mathrm{Na}_{2} \mathrm{SO}_{4}\right)$, filtered, and concentrated in vacuo to yield the title compound (S10) $(0.176 \mathrm{~g}, 80 \%)$ as a pale-yellow solid. $R_{f} 0.37$ ( $5 \%$ ethanol:chloroform); mp $126-130^{\circ} \mathrm{C}$ (from chloroform) [lit., ${ }^{88} 141-143{ }^{\circ} \mathrm{C}$ (from ethyl acetate) ]; ${ }^{1} \mathrm{H}$ NMR $\left(400 \mathrm{MHz}, \mathrm{CD}_{3} \mathrm{OD}\right) \delta_{\mathrm{H}}$ $7.10(1 \mathrm{H}, \mathrm{s}), 4.66(2 \mathrm{H}, \mathrm{s}), 4.04(3 \mathrm{H}, \mathrm{s})$; LRMS $\mathrm{m} / z\left(\mathrm{ESI}^{+}\right) 180\left([\mathrm{M}+\mathrm{Na}]^{+}\right.$, $45 \%), 170(80 \%), 158\left([\mathrm{M}+\mathrm{H}]^{+}, 100 \%\right), 113(31 \%)$. The spectroscopic data are consistent with literature. ${ }^{29,88}$

(1-Methyl-2-nitro-imidazol-5-yl)methyl chloride (15) 29, 87-88

Methanesulfonyl chloride $(74 \mu \mathrm{L}, 0.96 \mathrm{mmol}, 1.5 \mathrm{eq})$ was added dropwise to a stirred solution of (1-methyl-2-nitro-imidazol-5-yl)methanol (S10) $(0.10 \mathrm{~g}, 0.64 \mathrm{mmol}, 1.0 \mathrm{eq})$ in pyridine $(1.3 \mathrm{~mL})$ and stirred at $\mathrm{rt}$ for $3 \mathrm{~h}$ then concentrated in vacuo. Purification by filtration through a short pad of silica, eluting with $50 \%$ ethyl acetate:petroleum ether, yielded the title compound (15) $(75 \mathrm{mg}, 67 \%)$ as a colorless solid. $R_{f} 0.43$ (50\% ethyl acetate:petroleum ether). Mp $68-77^{\circ} \mathrm{C}$ (from dichloromethane) [lit. ${ }^{88} 87-90{ }^{\circ} \mathrm{C}$ (from ethyl acetate)]; ${ }^{1} \mathrm{H}$ NMR $\left(400 \mathrm{MHz}, \mathrm{CDCl}_{3}\right) \delta_{\mathrm{H}} 7.19(1 \mathrm{H}, \mathrm{s}), 4.62(2 \mathrm{H}, \mathrm{s}), 4.07$ $(3 \mathrm{H}, \mathrm{s})$; LRMS $\mathrm{m} / z\left(\mathrm{ESI}^{+}\right) 176\left([\mathrm{M}+\mathrm{H}]^{+}, 100 \%\right), 140(43 \%)$. The spectroscopic data are consistent with literature. ${ }^{29,88}$

(E)-Methyl-3-(4-[ tert-butyloxycarbonyl-(2-[1-(tert-butyloxycarbonyl)-2methyl-1 $H$-indol-3-ylethyl] amino)methyl]phenyl)prop-2-enoate (17) Di-tert-butyl dicarbonate $(1.0 \mathrm{~mL}, 4.2 \mathrm{mmol}, 3.0 \mathrm{eq})$ was added to a solution of $16(0.48 \mathrm{~g}, 1.4 \mathrm{mmol}, 1.0 \mathrm{eq})$ and $N, N$-dimethyl-4-aminopyridine $(8.0 \mathrm{mg}, 0.066 \mathrm{mmol}, 0.05 \mathrm{eq})$ in tetrahydrofuran $(14 \mathrm{~mL})$ and stirred at $\mathrm{rt}$ for $18 \mathrm{~h}$. The reaction was quenched with water $(20 \mathrm{~mL})$ and extracted with ethyl acetate $(2 \times 50 \mathrm{~mL})$. The organic components were combined and washed with water $(50 \mathrm{~mL})$, brine $(50 \mathrm{~mL})$ then dried $\left(\mathrm{MgSO}_{4}\right)$, filtered, and concentrated in vacuo. Purification using column chromatography, eluting with 0-60\% ethyl acetate:petroleum ether, yielded the title compound (17) $(0.62 \mathrm{~g}, 82 \%)$ as a colorless oil. $R f 0.71$ (50\% ethyl acetate:petroleum ether); $\bar{v}_{\max }($ thin film $) / \mathrm{cm}^{-1} 2976,1722,1690,1478,1368,1323,1254$, 1168,$1137 ;{ }^{1} \mathrm{H}$ NMR at $363 \mathrm{~K}\left(500 \mathrm{MHz},\left(\mathrm{D}_{6}\right.\right.$-DMSO) $\delta_{\mathrm{H}} 8.00(1 \mathrm{H}, \mathrm{d}, J$ 8.1), 7.66-7.57 (3H, m), 7.42 (1H, d, J7.2), 7.25 (2H, d, J7.8), 7.23-7.13 $(2 \mathrm{H}, \mathrm{m}), 6.53(1 \mathrm{H}, \mathrm{d}, J 16.1), 4.42(2 \mathrm{H}, \mathrm{s}), 3.74(3 \mathrm{H}, \mathrm{s}), 3.33(2 \mathrm{H}, \mathrm{t}, J 7.1)$, 2.84 (2H, t, J7.1), 2.46 (3H, s), $1.64(9 \mathrm{H}, \mathrm{s}), 1.34(9 \mathrm{H}, \mathrm{s}) ;{ }^{13} \mathrm{C}$ NMR at $363 \mathrm{~K}\left(126 \mathrm{MHz},\left(\mathrm{D}_{6}-\mathrm{DMSO}\right) \delta_{\mathrm{C}} 166.0,154.5,149.6,143.5,140.8,134.9\right.$, $132.9,132.6,129.1,127.8,127.4,122.7,121.8,117.3,117.2,114.8,114.4$,
83.1, 78.5, 50.8, 49.6, 46.1, 27.5, 27.4, 22.1, 12.7; HRMS $m / z\left(\mathrm{ESI}^{+}\right)$Found: 549.2953, $\mathrm{C}_{32} \mathrm{H}_{41} \mathrm{~N}_{2} \mathrm{O}_{6}$ requires $[\mathrm{M}+\mathrm{H}]^{+}$549.2959; LRMS (ESI $\left.{ }^{+}\right) 338$ $\left([\mathrm{M}+2 \mathrm{Na}+2 \mathrm{MeCN}]^{2+}, 23 \%\right), 225\left([\mathrm{M}+2 \mathrm{Na}+\mathrm{H}+2 \mathrm{MeCN}]^{3+}, 100 \%\right), 202$ (26\%), 123 (71\%); HPLC Method C, Retention time - 15.0 min, 99\%.

(E)-3-(4-[(tert-Butyloxycarbonyl-[2-(1-[tert-butyloxycarbonyl]-2-methyl$1 H$-indol-3-yl)ethyl] amino)methyl]phenyl)prop-2-enoic acid (18)

A solution of lithium hydroxide $(2.05 \mathrm{~g}, 85.6 \mathrm{mmol}, 10.0 \mathrm{eq})$ in water $(57 \mathrm{~mL})$ was slowly added to a stirred solution of $17(4.70 \mathrm{~g}, 8.56 \mathrm{mmol}$, $1.0 \mathrm{eq})$ in tetrahydrofuran $(57 \mathrm{~mL})$ and methanol $(57 \mathrm{~mL})$ at $0{ }^{\circ} \mathrm{C}$. The reaction mixture was stirred at $\mathrm{rt}$ for $6 \mathrm{~h}$ then diluted with ethyl acetate $(250 \mathrm{~mL})$, and quenched with aqueous $1 \mathrm{M}$ hydrochloric acid $(200 \mathrm{~mL})$. The reaction was extracted with ethyl acetate $(3 \times 200 \mathrm{~mL})$ and the organic components were combined and washed with water $(300 \mathrm{~mL})$, brine $(300 \mathrm{~mL})$ then dried $\left(\mathrm{MgSO}_{4}\right)$, filtered, and concentrated in vacuo to yield the title compound (18) (4.54 g, 99\%) as a colorless fluffy, foamy solid. $R_{f}$ 0.61 (100\% ethyl acetate); mp $94-96^{\circ} \mathrm{C}$ (from THF); $\bar{v}_{\max }$ (thin film) $/ \mathrm{cm}^{-1}$ $2976,2930,1726,1687,1410,1366,1258,1136,1116 ;{ }^{1} \mathrm{H}$ NMR at $363 \mathrm{~K}$ $\left(500 \mathrm{MHz},\left(\mathrm{D}_{6}-\mathrm{DMSO}\right) \delta_{\mathrm{H}} 8.00(1 \mathrm{H}, \mathrm{d}, J 8.0), 7.57(2 \mathrm{H}, \mathrm{d}, J 7.7), 7.55(1 \mathrm{H}\right.$, d, J15.9), $7.42(1 \mathrm{H}, \mathrm{d}, J 7.4), 7.24(2 \mathrm{H}, \mathrm{d}, J 7.7), 7.23-7.13(2 \mathrm{H}, \mathrm{m}), 6.44$ $(1 \mathrm{H}, \mathrm{d}, J 15.9), 4.41(2 \mathrm{H}, \mathrm{s}), 3.33(2 \mathrm{H}, \mathrm{t}, J 7.2), 2.84(2 \mathrm{H}, \mathrm{t}, J 7.2), 2.46(3 \mathrm{H}$, s), $1.64(9 \mathrm{H}, \mathrm{s}), 1.34(9 \mathrm{H}, \mathrm{s}) ;{ }^{13} \mathrm{C}$ NMR at $363 \mathrm{~K}\left(126 \mathrm{MHz},\left(\mathrm{D}_{6}-\mathrm{DMSO}\right)\right.$ $\delta_{\mathrm{C}} 166.8,154.5,149.6,142.7,140.4,134.9,132.94,132.93,129.1,127.6$, 127.4, 122.7, 121.8, 118.9, 117.2, 114.8, 114.4, 83.2, 78.5, 49.6, 46.1, 27.5, 27.4, 22.1, 12.8; HRMS $m / z$ (ESI ${ }^{-}$Found: $533.2648, \mathrm{C}_{31} \mathrm{H}_{37} \mathrm{~N}_{2} \mathrm{O}_{6}$ requires $[\mathrm{M}-\mathrm{H}]^{-}$533.2657; LRMS (ESI- $) 533\left([\mathrm{M}-\mathrm{H}]^{-}, 100 \%\right)$; HPLC Method A, Retention time - $13.1 \mathrm{~min}, 99 \%$.

(E)-tert-Butyl-3-(2-((4-(3-((benzyloxy)amino)-3-oxoprop-1-en-1-yl)benzyl)(tert-butoxycarbonyl)amino)ethyl)-2-methyl-1 $H$-indole-1-carboxylate (19)

PyBOP $(0.11 \mathrm{~g}, 0.21 \mathrm{mmol}, 1.1 \mathrm{eq})$ was added to a solution of $\mathbf{1 8}(0.10 \mathrm{~g}$, $0.19 \mathrm{mmol}, 1.0 \mathrm{eq})$ and triethylamine $(0.10 \mathrm{~mL}, 0.75 \mathrm{mmol}, 4.0 \mathrm{eq})$ in dry tetrahydrofuran $(1.9 \mathrm{~mL})$. The reaction mixture was stirred for $15 \mathrm{~min}$ at $\mathrm{rt}$ before $O$-(benzyl)-hydroxylamine hydrochloride (29) $(36 \mathrm{mg}, 0.22 \mathrm{mmol}$, $1.2 \mathrm{eq})$ was added. Stirring was continued at $\mathrm{rt}$ for $18 \mathrm{~h}$, the reaction mixture was diluted with ethyl acetate $(20 \mathrm{~mL})$ and quenched with aqueous $1 \mathrm{M}$ solution of hydrochloric acid $(10 \mathrm{~mL})$. The reaction mixture was extracted with ethyl acetate $(20 \mathrm{~mL})$, the organic components were washed with a saturated solution of sodium hydrogen carbonate $(40 \mathrm{~mL})$, water $(40 \mathrm{~mL})$, brine $(40 \mathrm{~mL})$, dried $\left(\mathrm{MgSO}_{4}\right)$, filtered, and concentrated in vacuo. Purification using column chromatography, eluting with $0-5 \%$ ethanol:chloroform, then a second purification using column chromatography, eluting with $0-50 \%$ ethyl acetate:petroleum ether, yielded the title compound (19) $(87 \mathrm{mg}, 73 \%)$ as a colorless solid. $R_{f} 0.45$ (50\% ethyl acetate:petroleum ether); $\mathrm{mp} 71-74^{\circ} \mathrm{C}$ (from dichloromethane:hexane); $\bar{v}_{\max }$ (thin film) $/ \mathrm{cm}^{-1}$ 3192, 2976, 1728, 1687, 1660, 1514, 1459, 1366, 1322, 1252, 1158, 1136, 1117,$1046 ;{ }^{1} \mathrm{H}$ NMR at $363 \mathrm{~K}\left(500 \mathrm{MHz}, \mathrm{D}_{6}-\mathrm{DMSO}\right) \delta_{\mathrm{H}} 11.71(1 \mathrm{H}, \mathrm{s})$, $8.82(1 \mathrm{H}, \mathrm{d}, J 7.8), 8.30(2 \mathrm{H}, \mathrm{d}, J 8.4), 8.30(1 \mathrm{H}, \mathrm{d}, J 15.8), 8.29-8.13(6 \mathrm{H}$, $\mathrm{m}), 8.06(2 \mathrm{H}, \mathrm{d}, J 8.0), 8.02(1 \mathrm{H}, \mathrm{ddd}, J 7.8,7.3,1.1), 7.98(1 \mathrm{H}, \mathrm{ddd}, J 7.5$, 7.3, 1.3), $7.30(1 \mathrm{H}, \mathrm{d}, J 15.8), 5.71(2 \mathrm{H}, \mathrm{s}), 5.22(2 \mathrm{H}, \mathrm{s}), 4.15(2 \mathrm{H}, \mathrm{t}, J 7.2)$, $3.65(2 \mathrm{H}, \mathrm{t}, J 7.2), 3.27(3 \mathrm{H}, \mathrm{s}), 2.45(9 \mathrm{H}, \mathrm{s}), 2.16(9 \mathrm{H}, \mathrm{s}) ;{ }^{13} \mathrm{C} \mathrm{NMR}$ at $363 \mathrm{~K}$ $\left(126 \mathrm{MHz}, \mathrm{D}_{6}\right.$-DMSO) $\delta_{\mathrm{C}} 163.3,{ }^{*} 154.4,149.5,139.9,138.9,135.7,134.9$, 133.3, 132.9, 129.1, 128.2, 127.7, 127.6, 127.4, 127.1, 122.7, 121.7, 118.1 $117.1,114.8,114.4,83.1,78.5,76.9,49.5,46.1,27.5,27.4,22.1,12.7$; HRMS $\mathrm{m} / \mathrm{z}\left(\mathrm{ESI}^{+}\right)$Found: $640.33788, \mathrm{C}_{38} \mathrm{H}_{46} \mathrm{~N}_{3} \mathrm{O}_{6}$ requires $[\mathrm{M}+\mathrm{H}]^{+} 640.33811$; LRMS (ESI $\left.{ }^{+}\right) 662\left([\mathrm{M}+\mathrm{Na}]^{+}, 16 \%\right), 606(34 \%), 562(20 \%), 506(38 \%), 461$ (44\%), 423 (38\%), 405 (13\%), $361(100 \%), 317(26 \%), 300(25 \%), 282$ (39\%), 266 (10\%); HPLC Method A, Retention time - $13.3 \mathrm{~min},>99 \%$. ${ }^{*}$ Signal at 163.3 observed by ${ }^{1} \mathrm{H}_{-}{ }^{13} \mathrm{C}$ HMBC correlation see SI for details.

(E)-tert-Butyl-3-(2-((tert-butoxycarbonyl) (4-(3-(((4-nitrobenzyl)oxy)amino)-3-oxoprop-1-en-1-yl)benzyl)amino)ethyl)-2-methyl-1 $H$ indole-1-carboxylate (20)

PyBOP ( $48 \mathrm{mg}, 0.093 \mathrm{mmol}, 1.1 \mathrm{eq}$ ) was added to a solution of 18 ( $45 \mathrm{mg}$, $0.084 \mathrm{mmol}, 1.0 \mathrm{eq})$ and triethyl amine $(35 \mu \mathrm{L}, 0.25 \mathrm{mmol}, 3.0 \mathrm{eq})$ in dry tetrahydrofuran $(1.0 \mathrm{~mL})$. The reaction mixture was stirred for $15 \mathrm{~min}$ at $\mathrm{rt}$ 
before $O$-(4-nitrobenzyl)-hydroxylamine (5) $(17 \mathrm{mg}, 0.10 \mathrm{mmol}, 1.2 \mathrm{eq})$ was added. Stirring was continued at $\mathrm{rt}$ for $18 \mathrm{~h}$, the reaction mixture was diluted with ethyl acetate $(20 \mathrm{~mL})$ and quenched with an aqueous $1 \mathrm{M}$ solution of hydrochloric acid $(10 \mathrm{~mL})$. The reaction mixture was extracted with ethyl acetate $(20 \mathrm{~mL})$, the organic components were washed with a saturated aqueous solution of sodium hydrogen carbonate $(40 \mathrm{~mL})$, water $(40 \mathrm{~mL})$, brine $(40 \mathrm{~mL})$, dried $\left(\mathrm{MgSO}_{4}\right)$, filtered, and concentrated in vacuo. Purification using column chromatography, eluting with $0-10 \%$ ethanol:chloroform, yielded the title compound (20) (54 mg, 92\%) as a paleyellow solid. $R_{f}$; mp $90-92{ }^{\circ} \mathrm{C}$ (from DMSO: $\mathrm{H}_{2} \mathrm{O}$ ); $\bar{\nu}_{\max }$ (thin film) $/ \mathrm{cm}^{-1}$ $3199,2978,1728,1688,1523,1460,1346,1323,1159,1137,1117 ;{ }^{1} \mathrm{H}$ NMR at $363 \mathrm{~K}\left(500 \mathrm{MHz},\left(\mathrm{D}_{6}-\mathrm{DMSO}\right) \delta_{\mathrm{H}} 11.04(1 \mathrm{H}, \mathrm{br} \mathrm{s}), 8.22(2 \mathrm{H}, \mathrm{d}, J 8.3)\right.$, $8.00(1 \mathrm{H}, \mathrm{d}, J 8.1), 7.72(2 \mathrm{H}, \mathrm{d}, J 8.3), 7.50(2 \mathrm{H}, \mathrm{d}, J 7.9), 7.50(1 \mathrm{H}, \mathrm{d}, J 15.9)$ $7.41(1 \mathrm{H}, \mathrm{d}, J 7.6), 7.24(2 \mathrm{H}, \mathrm{d}, J 7.9), 7.23-7.13(2 \mathrm{H}, \mathrm{m}), 6.46(1 \mathrm{H}, \mathrm{d}, J$ 15.9), $5.05(2 \mathrm{H}, \mathrm{s}), 4.41(2 \mathrm{H}, \mathrm{s}), 3.33(2 \mathrm{H}, \mathrm{t}, J 7.4), 2.84(2 \mathrm{H}, \mathrm{t}, J 7.4), 2.46$ $(3 \mathrm{H}, \mathrm{s}), 1.64(9 \mathrm{H}, \mathrm{s}), 1.35(9 \mathrm{H}, \mathrm{s}) ;{ }^{13} \mathrm{C} \mathrm{NMR}$ at $363 \mathrm{~K}(126 \mathrm{MHz}$, $\left.\left(\mathrm{CD}_{3}\right)_{2} \mathrm{SO}\right) \delta_{\mathrm{C}} 163.5,{ }^{*} 154.4,149.5,147.1,143.4,140.0,139.2,134.9,133.2$, $132.9,129.1,128.9,127.4,127.2,122.8,122.7,121.7,117.8,117.1,114.8$ $114.4,83.1,78.5,75.6,49.6,{ }^{*} 46.1,27.5,27.4,22.1,12.7 ; \mathrm{HRMS} \mathrm{m} / z\left(\mathrm{ESI}^{-}\right)$ Found: 683.3083, $\mathrm{C}_{38} \mathrm{H}_{43} \mathrm{~N}_{4} \mathrm{O}_{8}$ requires $[\mathrm{M}-\mathrm{H}]^{-}$683.3086; LRMS (ESI ${ }^{-}$) $683\left([\mathrm{M}-\mathrm{H}]^{-}, 100 \%\right)$; HPLC Method B, Retention time - $13.3 \mathrm{~min}, 98 \%$. ${ }^{*}$ Signal at 163.5 observed by ${ }^{1} \mathrm{H}-{ }^{13} \mathrm{C}$ HMBC correlation, signal at $49.6 \mathrm{ob}-$ served by ${ }^{1} \mathrm{H}^{-13} \mathrm{C}$ HSQC correlation see SI for details.

(E)-tert-Butyl-3-(2-((tert-butoxycarbonyl) (4-(3-(((5-nitrothiophen-2yl)methoxy)amino)-3-oxoprop-1-en-1-yl)benzyl)amino)ethyl)-2-methyl$1 H$-indole-1-carboxylate (21)

PyBOP $(0.15 \mathrm{~g}, 0.29 \mathrm{mmol}, 1.1 \mathrm{eq})$ was added to a solution of $18(0.14 \mathrm{~g}$, $0.26 \mathrm{mmol}, 1.0 \mathrm{eq})$ and triethylamine $(0.11 \mathrm{~mL}, 0.79 \mathrm{mmol}, 3.0 \mathrm{eq})$ in dry tetrahydrofuran $(2.6 \mathrm{~mL})$. The reaction mixture was stirred for $15 \mathrm{~min}$ at $\mathrm{rt}$ before $O$-(5-nitrothiophen-2-yl)methylene)hydroxylamine (8) $(55 \mathrm{mg}$, $0.32 \mathrm{mmol}, 1.2 \mathrm{eq}$ ) was added. Stirring was continued at $\mathrm{rt}$ for $18 \mathrm{~h}$, the reaction mixture was diluted with ethyl acetate $(20 \mathrm{~mL})$ and quenched with aqueous $1 \mathrm{M}$ solution of hydrochloric acid $(10 \mathrm{~mL})$. The reaction mixture was extracted with ethyl acetate $(20 \mathrm{~mL})$, the organic components were washed with a saturated solution of sodium hydrogen carbonate $(40 \mathrm{~mL})$, water $(40 \mathrm{~mL})$, brine $(40 \mathrm{~mL})$, dried $\left(\mathrm{MgSO}_{4}\right)$, filtered, and concentrated in vacuo. Purification using column chromatography, eluting with $2.5 \%$ ethanol:chloroform, yielded the title compound (21) $(0.15 \mathrm{~g}, 84 \%)$ as a pale yellow solid. $R_{f} 0.59$ ( $5 \%$ ethanol:chloroform); $\mathrm{mp} 80-82^{\circ} \mathrm{C}$ (from hexane:dichloromethane); $\bar{v}_{\max }$ (thin film) $/ \mathrm{cm}^{-1} 3205,2977,1728,1684,1460,1336$, 1158,$1138 ;{ }^{1} \mathrm{H}$ NMR Major rotamer at room temperature reported $\left(400 \mathrm{MHz}, \mathrm{CDCl}_{3}\right) \delta_{\mathrm{H}} 8.41(1 \mathrm{H}, \mathrm{br} \mathrm{s}), 8.07(1 \mathrm{H}, \mathrm{d}, J 8.2), 7.82(1 \mathrm{H}, \mathrm{d}, J 4.1)$, $7.71(1 \mathrm{H}, \mathrm{d}, J 15.9), 7.48-6.97(8 \mathrm{H}, \mathrm{m}), 6.35(1 \mathrm{H}, \mathrm{d}, J 15.9), 5.12(2 \mathrm{H}, \mathrm{s})$, $4.43(2 \mathrm{H}, \mathrm{s}), 3.30(2 \mathrm{H}, \mathrm{s}), 2.82(2 \mathrm{H}, \mathrm{s}), 2.47(3 \mathrm{H}, \mathrm{s}), 1.67(9 \mathrm{H}, \mathrm{s}), 1.46(9 \mathrm{H}$, s); ${ }^{13} \mathrm{C}$ NMR spectroscopic data not collected due to instability of compound at prolonged high temperatures;. HRMS $\mathrm{m} / z\left(\mathrm{ESI}^{-}\right)$Found: 689.26561, $\mathrm{C}_{36} \mathrm{H}_{41} \mathrm{O}_{8} \mathrm{~N}_{4} \mathrm{~S}$ requires $[\mathrm{M}-\mathrm{H}]^{-}$689.26506; LRMS $\left(\mathrm{ESI}^{-}\right) 689$ ([M-H] $\left.]^{-}, 45 \%\right), 532$ (7\%), 432 (5\%), 144 (100\%); HPLC Method B, Retention time - $13.5 \mathrm{~min}, 96 \%$.

(E)-tert-Butyl-3-(2-((tert-butoxycarbonyl) (4-(3-(((6-nitroquinolin-5yl)methoxy)amino)-3-oxoprop-1-en-1-yl)benzyl)amino)ethyl)-2-methyl1H-indole-1-carboxylate (22)

PyBOP ( $85 \mathrm{mg}, 0.16 \mathrm{mmol}, 1.1 \mathrm{eq})$ was added to a solution of $18(79 \mathrm{mg}$, $0.15 \mathrm{mmol}, 1.0 \mathrm{eq})$ and triethylamine $(62 \mu \mathrm{L}, 0.45 \mathrm{mmol}, 3.0 \mathrm{eq})$ in dry tetrahydrofuran $(1.5 \mathrm{~mL})$. The reaction mixture was stirred for $15 \mathrm{~min}$ at $\mathrm{rt}$ before $O$-(6-nitroquinolin-5-yl)-hydroxylamine (12) $(39 \mathrm{mg}, 0.18 \mathrm{mmol}$, $1.2 \mathrm{eq})$ was added. Stirring was continued at $\mathrm{rt}$ for $18 \mathrm{~h}$, the reaction mixture was diluted with ethyl acetate $(20 \mathrm{~mL})$ and quenched with aqueous $1 \mathrm{M}$ solution of hydrochloric acid $(10 \mathrm{~mL})$. The reaction mixture was extracted with ethyl acetate $(20 \mathrm{~mL})$, the organic components were washed with a saturated solution of sodium hydrogen carbonate $(40 \mathrm{~mL})$, water $(40 \mathrm{~mL})$, brine $(40 \mathrm{~mL})$, dried $\left(\mathrm{MgSO}_{4}\right)$, filtered, and concentrated in vacuo. Purification using column chromatography, eluting with $0-10 \%$ ethanol:chloroform, then a second purification by column chromatography, eluting with 0 $100 \%$ ethyl acetate:petroleum ether, yielded the title compound (22) (66 mg, 60\%) as a colorless solid. $R_{f} 0.44$ (80\% ethyl acetate:petroleum ether); $\mathrm{mp} 106-110^{\circ} \mathrm{C}$ (from dichloromethane:hexane); $\bar{v}_{\max }$ (thin film) $/ \mathrm{cm}^{-1} 3189,2976,2930,1731,1687,1634,1531,1459,1366,1323$, $1259,1160,1138,1117 ;{ }^{1} \mathrm{H}$ NMR at $363 \mathrm{~K}\left(500 \mathrm{MHz},\left(\mathrm{D}_{6}\right.\right.$-DMSO) $\delta_{\mathrm{H}}$ $11.21(1 \mathrm{H}, \mathrm{s}), 9.21(1 \mathrm{H}, \mathrm{d}, J 8.7), 9.11(1 \mathrm{H}, \mathrm{dd}, J 4.1,1.6), 8.25(1 \mathrm{H}, \mathrm{d}, J$ 9.1), $8.15(1 \mathrm{H}, \mathrm{d}, J 9.1), 8.00(1 \mathrm{H}, \mathrm{d}, J 8.1), 7.79(1 \mathrm{H}, \mathrm{dd}, J 8.7,4.1), 7.51$ $(1 \mathrm{H}, \mathrm{d}, J 15.7), 7.48(2 \mathrm{H}, \mathrm{d}, J 7.8), 7.42(1 \mathrm{H}, \mathrm{d}, J 7.5), 7.25(2 \mathrm{H}, \mathrm{d}, J 7.8)$, 7.23-7.14 (2H, m), $6.42(1 \mathrm{H}, \mathrm{d}, J 15.7), 5.54(2 \mathrm{H}, \mathrm{s}), 4.41(2 \mathrm{H}, \mathrm{s}), 3.33(2 \mathrm{H}$, $\mathrm{t}, J 7.2), 2.84(2 \mathrm{H}, \mathrm{t}, J 7.2), 2.46(3 \mathrm{H}, \mathrm{s}), 1.64(9 \mathrm{H}, \mathrm{s}), 1.35(9 \mathrm{H}, \mathrm{s}) ;{ }^{13} \mathrm{C}$ NMR at $363 \mathrm{~K}\left(126 \mathrm{MHz},\left(\mathrm{D}_{6}\right.\right.$-DMSO) $\delta_{\mathrm{C}} 163.8,{ }^{*} 154.4,152.6,149.6,148.1$, $147.9,140.1,139.4,134.9,134.8,133.2$, 132.9, 131.7, 129.1, 127.5, 127.2, 127.0, 125.9, 122.8, 122.72, 122.68, 121.8, 117.5, 117.1, 114.8, 114.4, 83.1, 78.5, 67.7, 49.6, ${ }^{*} 46.1,27.5,27.4,22.1,12.7$; HRMS $m / z\left(\mathrm{ESI}^{+}\right)$Found: 736.33361, $\mathrm{C}_{41} \mathrm{H}_{46} \mathrm{~N}_{5} \mathrm{O}_{8}$ requires $[\mathrm{M}+\mathrm{H}]^{+}$736.33409; LRMS $\left(\mathrm{ESI}^{-}\right) 770$ ([M+Cl] $\left.]^{-}, 49 \%\right), 734\left([\mathrm{M}-\mathrm{H}]^{-}, 81 \%\right), 354$ (38\%), 185 (100\%), 141 (96\%). HPLC Method A, Retention time - 14.0 min, 98\%. ${ }^{*}$ Signals at 163.8 and 49.6 observed by ${ }^{1} \mathrm{H}^{-13} \mathrm{C}$ HMBC correlation see SI for details.

(E)-N-(4-(3-((Benzyloxy)amino)-3-oxoprop-1-en-1-yl)benzyl)-2-(2-methyl-1 $H$-indol-3-yl)ethan-1-aminium 2,2,2-trifluoroacetate (Bn-Pano, 23) Trifluoroacetic acid $(1.6 \mathrm{~mL}, 20 \% \mathrm{v} / \mathrm{v})$ was added dropwise to a rapidly stirred solution of $19(50 \mathrm{mg}, 78 \mu \mathrm{mol}, 1.0 \mathrm{eq})$ and triisopropylsilane $(3.4 \mu \mathrm{L}, 16 \mu \mathrm{mol}, 0.2 \mathrm{eq})$ in dichloromethane $(7.8 \mathrm{~mL})$. The reaction mixture was stirred for 60 mins then diluted with toluene $(1 \mathrm{~mL})$ and dried by azeotroping with toluene $(3 \times 1 \mathrm{~mL})$ in vacuo. Purification using column chromatography, eluting with $10 \%$ ethanol:chloroform, yielded the title compound (23) (34 mg, 79\%) as a colorless solid. $R f 0.25$ (10\% ethanol: chloroform); Mp $102-104^{\circ} \mathrm{C}$ (Decomposed from methanol); $\bar{\nu}_{\max }$ (thin film) $/ \mathrm{cm}^{-1}$; 3391, 3268, 3031, 2950, 2851, 162, 1624, 1461, 1341, 1202, 1046,$978 ;{ }^{1} \mathrm{H}$ NMR $\left(500 \mathrm{MHz}, \mathrm{CD}_{3} \mathrm{OD}\right) \delta_{\mathrm{H}} 7.61(1 \mathrm{H}, \mathrm{d}, J 16.1), 7.60(2 \mathrm{H}$, d, J7.7), $7.46(2 \mathrm{H}, \mathrm{d}, J 8.2), 7.41(1 \mathrm{H}, \mathrm{d}, J 8.1), 7.43-7.33(4 \mathrm{H}, \mathrm{m}), 7.25$ $(1 \mathrm{H}, \mathrm{d}, J 7.8), 7.03(1 \mathrm{H}, \mathrm{ddd}, J 8.1,7.1,1.2), 6.96(1 \mathrm{H}, \mathrm{ddd}, J 7.8,7.1,1.1)$, $6.46(1 \mathrm{H}, \mathrm{d}, J 16.1), 4.93(2 \mathrm{H}, \mathrm{s}), 4.16(2 \mathrm{H}, \mathrm{s}), 3.18-3.12(2 \mathrm{H}, \mathrm{m}), 3.12-$ $3.06(2 \mathrm{H}, \mathrm{m}), 2.39(3 \mathrm{H}, \mathrm{s}) ;{ }^{13} \mathrm{C}$ NMR $\left(126 \mathrm{MHz}, \mathrm{CD}_{3} \mathrm{OD}\right) \delta_{\mathrm{c}} 165.8,141.5$, 137.2, 137.0, 136.9, 135.7, 133.8, 131.3, 130.3, 129.7, 129.53, 129.46, 129.3, 121.8, 119.8, 119.3, 118.0, 111.6, 106.2, 79.2, 52.1, 49.1, ${ }^{*} 22.7,11.3$; HRMS $\mathrm{m} / \mathrm{z}\left(\mathrm{ESI}^{+}\right)$Found: $440.23323 \mathrm{C}_{28} \mathrm{H}_{30} \mathrm{~N}_{3} \mathrm{O}_{2}$ requires $[\mathrm{M}+\mathrm{H}]^{+}$440.23325; LRMS $\left(\mathrm{ESI}^{+}\right) 440\left([\mathrm{M}+\mathrm{H}]^{+}, 63 \%\right), 423(28 \%), 150(100 \%) ;$ HPLC Method A, Retention time - $8.0 \mathrm{~min}, 99 \%$. All batches used for biological testing were $>95 \%$ purity. Signal at 49.1 observed by ${ }^{1} \mathrm{H}-{ }^{13} \mathrm{C}$ HMBC correlation see SI for details.

(E)-2-(2-Methyl-1 $H$-indol-3-yl)- $N$-(4-(3-(((4-nitrobenzyl)oxy)amino)-3oxoprop-1-en-1-yl)benzyl)ethan-1-aminium 2,2,2-trifluoroacetate (NBPano, 24)

Trifluoroacetic acid $(0.16 \mathrm{~mL}, 20 \% \mathrm{v} / \mathrm{v})$ was added dropwise to a rapidly stirred solution of $20(22 \mathrm{mg}, 0.32 \mathrm{mmol}, 1.0 \mathrm{eq})$ and triisopropylsilane $(1.3 \mu \mathrm{L}, 6.4 \mu \mathrm{mol}, 0.2 \mathrm{eq})$ in dichloromethane $(0.8 \mathrm{~mL})$. The reaction mixture was stirred for 75 mins then diluted with toluene $(1 \mathrm{~mL})$ and dried by azeotroping with toluene $(3 \times 1 \mathrm{~mL})$ in vacuo. Purification using column chromatography, eluting with 2:5:80 water:isopropanol:ethyl acetate, to yield the title compound $(24)(13 \mathrm{mg}, 69 \%)$ as an off-white solid. $R_{f} 0.55$ (1:3:40 water:isopropanol:ethyl acetate), $R_{f} 0.21$ ( $10 \%$ ethanol:chloroform); mp $98-100^{\circ} \mathrm{C}$ (dec.; from ethanol); $\bar{v}_{\max }$ (thin film) $/ \mathrm{cm}^{-1} 3399$, 3293, 2922, 2852, 1669, 1629, 1520, 1462, 1345, 1202, 1014; ${ }^{1} \mathrm{H}$ NMR $\left(500 \mathrm{MHz}, \mathrm{CD}_{3} \mathrm{OD}\right) \delta_{\mathrm{H}} 8.25(2 \mathrm{H}, \mathrm{d}, J 8.7), 7.70(2 \mathrm{H}, \mathrm{d}, J 8.7), 7.57(1 \mathrm{H}, \mathrm{d}$, $J 15.8), 7.50(2 \mathrm{H}, \mathrm{d}, J 8.2), 7.38$ (1H, ddd, J7.9, 1.1, 1.0), $7.32(2 \mathrm{H}, \mathrm{d}, J 8.2)$, $7.23(1 \mathrm{H}, \mathrm{ddd}, J 8.1,1.0,1.0), 7.00(1 \mathrm{H}, \mathrm{ddd}, J 8.1,7.0,1.1), 6.93(1 \mathrm{H}, \mathrm{ddd}$, J7.9, 7.0, 1.0), $6.40(1 \mathrm{H}, \mathrm{d}, J 15.8), 5.06(2 \mathrm{H}, \mathrm{s}), 3.90(2 \mathrm{H}, \mathrm{s}), 3.01-2.91$ $(4 \mathrm{H}, \mathrm{m}), 2.35(3 \mathrm{H}, \mathrm{s}) ;{ }^{13} \mathrm{C} \mathrm{NMR}\left(126 \mathrm{MHz}, \mathrm{CD}_{3} \mathrm{OD}\right) \delta_{\mathrm{C}} 166.1,149.2$, 145.1, 141.0, 137.8, 137.2, 136.4, 133.6, 130.8, 130.5, 129.5, 129.2, 124.5, 121.6, 119.7, 119.3, 118.1, 111.5, 107.0, 77.3, 52.7, 49.4, 23.4, 11.3; HRMS $\mathrm{m} / \mathrm{z}\left(\mathrm{ESI}^{+}\right)$Found: 485.21835, $\mathrm{C}_{28} \mathrm{H}_{29} \mathrm{~N}_{4} \mathrm{O}_{4}$ requires $[\mathrm{M}+\mathrm{H}]^{+}$485.21833; LRMS (ESI $\left.{ }^{+}\right) 485$ ([M+H $\left.]^{+}, 100 \%\right), 468$ (4\%), 349 (4\%), 304 (3\%), 216 (4\%), 130 (2\%); HPLC Method B, Retention time - $8.4 \mathrm{~min}, 98-99 \%$ at 3 wavelengths, mean purity $98 \%$. All batches used for biological testing were $>95 \%$ purity. 
(E)-2-(2-Methyl-1 H-indol-3-yl)- $N$-(4-(3-(((5-nitrothiophen-2-yl)methoxy)amino)-3-oxoprop-1-en-1-yl)benzyl)ethan-1-aminium 2,2,2-trifluoroacetate (NT-Pano, 25)

Trifluoroacetic acid $(0.25 \mathrm{~mL}, 20 \% \mathrm{~V} / \mathrm{v})$ was added dropwise to a rapidly stirred solution of (21) $(9 \mathrm{mg}, 0.01 \mathrm{mmol}, 1.0 \mathrm{eq})$ and triisopropylsilane $(0.5 \mu \mathrm{L}, 3 \mu \mathrm{mol}, 0.2 \mathrm{eq})$ in dichloromethane $(1 \mathrm{~mL})$. The reaction mixture was stirred for 65 mins then diluted with toluene $(1 \mathrm{~mL})$ and dried by azeotroping with toluene $(3 \times 1 \mathrm{~mL})$ in vacuo. Purification using column chromatography, eluting with 1:2:10 $\mathrm{H}_{2} \mathrm{O}$ :isopropyl alcohol:ethyl acetate, yielded the title compound (25) ( $5 \mathrm{mg}, 64 \%)$ as a pale-yellow solid. $R_{f} 0.48$ (1:2:10 $\mathrm{H}_{2} \mathrm{O}$ : isopropyl alcohol:ethyl acetate), 0.38 (20\% ethanol:chloroform); $\mathrm{mp} 108-110^{\circ} \mathrm{C}$ (dec.; from $\mathrm{H}_{2} \mathrm{O}$ /isopropyl alcohol); $\bar{\nu}_{\max }$ (thin film $) / \mathrm{cm}^{-1} 3198,2924,1694,1503,1337,1179,1136 ;{ }^{1} \mathrm{H}$ NMR $(500 \mathrm{MHz}$ $\left.\mathrm{CD}_{3} \mathrm{OD}\right) \delta_{\mathrm{H}} 7.90(1 \mathrm{H}, \mathrm{d}, J 4.1), 7.60(1 \mathrm{H}, \mathrm{d}, J 15.8), 7.56(2 \mathrm{H}, \mathrm{d}, J 8.2), 7.41$ $(2 \mathrm{H}, \mathrm{d}, J 8.2), 7.40(1 \mathrm{H}, \mathrm{ddd}, J 7.9,1.2,0.9), 7.24(1 \mathrm{H}, \mathrm{ddd}, J 8.1,1.0,0.9)$, $7.18(1 \mathrm{H}, \mathrm{d}, J 4.1), 7.01(1 \mathrm{H}, \mathrm{ddd}, J 8.1,7.0,1.2), 6.95(1 \mathrm{H}, \mathrm{ddd}, J 7.9,7.0$, $1.0), 6.47(1 \mathrm{H}, \mathrm{d}, J 15.8), 5.12(2 \mathrm{H}, \mathrm{s}), 4.05(2 \mathrm{H}, \mathrm{s}), 3.10-3.00(4 \mathrm{H}, \mathrm{m}), 2.37$ $(3 \mathrm{H}, \mathrm{s}) ;{ }^{13} \mathrm{C}$ NMR $\left(126 \mathrm{MHz}, \mathrm{CD}_{3} \mathrm{OD}\right) \delta_{\mathrm{C}} 166.2,153.7,147.9,141.5,137.6$, 137.2, 136.4, 133.6, 130.9, 129.6, 129.5, 129.3, 128.9, 121.7, 119.7, 119.0, 118.1, 111.5, 106.9, 72.7, 52.6, 49.1, ${ }^{*} 23.3,11.3$; HRMS $m / z\left(\mathrm{ESI}^{+}\right)$Found: $491.17457 \mathrm{C}_{26} \mathrm{H}_{27} \mathrm{~N}_{4} \mathrm{O}_{4} \mathrm{~S}$ requires $[\mathrm{M}+\mathrm{H}]^{+}$491.17475; LRMS $\left(\mathrm{ESI}^{+}\right) 491$ $\left([\mathrm{M}+\mathrm{H}]^{+}, 58 \%\right), 349(22 \%), 301(41 \%), 107$ (100\%); HPLC Method B, Retention time - $8.1 \mathrm{~min}, 93-98 \%$, mean purity $95 \%$. All batches used for biological testing were $>95 \%$ purity. ${ }^{*}$ Signal at 49.1 observed by ${ }^{1} \mathrm{H}-{ }^{13} \mathrm{C}$ HMBC correlation see SI for details.

(E)-2-(2-Methyl-1 H-indol-3-yl)- $N$-(4-(3-(((6-nitroquinolin-5-yl)methoxy)amino)-3-oxoprop-1-en-1-yl)benzyl)ethan-1-aminium-2,2,2-trifluoroacetate (NQ-Pano, 26)

Trifluoroacetic acid $(0.98 \mathrm{~mL}, 20 \% \mathrm{~V} / \mathrm{V})$ was added dropwise to a rapidly stirred solution of $22(36 \mathrm{mg}, 0.49 \mathrm{mmol}, 1.0 \mathrm{eq})$ and triisopropylsilane $(2.0 \mu \mathrm{L}, 9.8 \mu \mathrm{mol}, 0.2 \mathrm{eq})$ in dichloromethane $(4.9 \mathrm{~mL})$. The reaction mixture was stirred for 55 mins then diluted with toluene $(1 \mathrm{~mL})$ and dried by azeotroping with toluene $(3 \times 1 \mathrm{~mL})$ in vacuo. Purification using column chromatography, eluting with $0-10 \%$ ethanol: chloroform, yielded the title compound (26) ( $31 \mathrm{mg}, 83 \%)$ as a yellow solid. $R_{f} 0.15$ (10\% ethanol:chloroform); mp $118-120^{\circ} \mathrm{C}$ (dec.; from methanol); $\bar{\nu}_{\max }$ (thin film) $/ \mathrm{cm}^{-1}$; $3398,3198,3054,2921,2852,1665,1626,1530,1462,1343,1047 ;{ }^{1} \mathrm{H}$ NMR $\left(500 \mathrm{MHz}, \mathrm{CD}_{3} \mathrm{OD}\right) \delta_{\mathrm{H}} 9.29(1 \mathrm{H}, \mathrm{d}, J 8.8), 9.07(1 \mathrm{H}, \mathrm{d}, J 3.8), 8.25(1 \mathrm{H}, \mathrm{d}$, J9.2), 8.14 (1H, d, J9.2), $7.80(1 \mathrm{H}, \mathrm{dd}, J 8.8,3.8), 7.58$ (1H, d, J15.8), 7.48 $(2 \mathrm{H}, \mathrm{d}, J 7.9), 7.39(1 \mathrm{H}, \mathrm{ddd}, J 7.9,1.1,0.9), 7.29(2 \mathrm{H}, \mathrm{d}, J 7.9), 7.24(1 \mathrm{H}$, ddd, J8.1, 1.0, 0.9), 7.01 (1H, ddd, J8.1, 7.0, 1.1), $6.93(1 \mathrm{H}, \mathrm{ddd}, J 7.9,7.0$, $1.0), 6.38(1 \mathrm{H}, \mathrm{d}, J 15.8), 5.62(2 \mathrm{H}, \mathrm{s}), 3.83(2 \mathrm{H}, \mathrm{s}), 2.95(2 \mathrm{H}, \mathrm{t}, J 7.1), 2.87$ $(2 \mathrm{H}, \mathrm{t}, J 7.1), 2.36(3 \mathrm{H}, \mathrm{s}) ;{ }^{13} \mathrm{C} \mathrm{NMR}\left(126 \mathrm{MHz}, \mathrm{CD}_{3} \mathrm{OD}\right) \delta_{\mathrm{C}} 166.7,154.0$, $150.5,149.6,142.1,141.9,137.5,137.2,135.2,133.2,132.7,130.1,129.8$, $129.4,129.1,127.8,125.0,124.4,121.4,119.5,118.3,118.0,111.3,108.4$, 69.4, 53.6, 50.1, 24.6, 11.4; HRMS $\mathrm{m} / z$ (ESI ${ }^{+}$) Found: 536.22894 $\mathrm{C}_{31} \mathrm{H}_{30} \mathrm{~N}_{5} \mathrm{O}_{4}$ requires $[\mathrm{M}+\mathrm{H}]^{+}$536.22923; LRMS $\left(\mathrm{ESI}^{+}\right) 536\left([\mathrm{M}+\mathrm{H}]^{+}\right.$, 7\%), 332 (6\%), 273 (6\%), 158 (100\%), 144 (35\%), 115 (36\%); HPLC Method B, Retention time - $7.7 \mathrm{~min}, 98-99 \%$, mean purity $99 \%$. All batches used for biological testing were $>95 \%$ purity.

(E)-tert-Butyl-3-(2-((tert-butoxycarbonyl)(4-(3-(hydroxyamino)-3-oxoprop-1-en-1-yl)benzyl)amino)ethyl)-2-methyl-1 $H$-indole-1-carboxylate (27)

1, 1'-Carbonyl diimidazole $(59 \mathrm{mg}, 0.36 \mathrm{mmol}, 1.5 \mathrm{eq})$ was added to a solution $18(0.13 \mathrm{~g}, 0.24 \mathrm{mmol}, 1.0 \mathrm{eq})$ in dry tetrahydrofuran $(0.8 \mathrm{~mL})$ and stirred at $\mathrm{rt}$ for $4 \mathrm{~h}$. Hydroxylamine hydrochloride $(34 \mathrm{mg}, 0.49 \mathrm{mmol}$, $2.0 \mathrm{eq}$ ) was added and stirring was continued for a further $19 \mathrm{~h}$. The reaction was quenched by addition of a $1 \mathrm{M}$ aqueous solution of hydrochloric acid $(10 \mathrm{~mL})$ then extracted with ethyl acetate $(2 \times 20 \mathrm{~mL})$. The organic components were washed with brine $(50 \mathrm{~mL})$, dried $\left(\mathrm{Na}_{2} \mathrm{SO}_{4}\right)$, filtered, and concentrated in vacuo. Purification by column chromatography (elution with 0 $10 \%$ ethanol:chloroform) yielded the title compound (27) (98 $\mathrm{mg}, 74 \%)$ as a yellow solid, which was used in the next step without further purification. Rf 0.32 (10\% ethanol:chloroform); mp $104-106^{\circ} \mathrm{C}$ (from ethanol); $\bar{\nu}_{\max }$ (thin film) $/ \mathrm{cm}^{-1} 3204,2976,2930,1727,1687,1460,1366,1323,1251$, $1159,1137,1117,1048 ;{ }^{1} \mathrm{H}$ NMR at $363 \mathrm{~K}\left(500 \mathrm{MHz}, \mathrm{D}_{6}\right.$-DMSO $) \delta_{\mathrm{H}} 10.44$
$(1 \mathrm{H}, \mathrm{s}), 8.21(1 \mathrm{H}, \mathrm{s}), 8.00(1 \mathrm{H}, \mathrm{d}, J 8.0), 7.49(2 \mathrm{H}, \mathrm{d}, J 8.1), 7.47-7.38(2 \mathrm{H}$, m), $7.24(2 \mathrm{H}, \mathrm{d}, J 8.1), 7.22-7.14(2 \mathrm{H}, \mathrm{m}), 6.51(1 \mathrm{H}, \mathrm{d}, J 15.5), 4.41(2 \mathrm{H}$, s), $3.33(2 \mathrm{H}, \mathrm{t}, J 7.2), 2.83(2 \mathrm{H}, \mathrm{t}, J 7.2), 2.46(3 \mathrm{H}, \mathrm{s}), 1.64(9 \mathrm{H}, \mathrm{s}), 1.35(9 \mathrm{H}$, s); ${ }^{13} \mathrm{C} \mathrm{NMR}^{*}$ at $363 \mathrm{~K}\left(126 \mathrm{MHz}, \mathrm{D}_{6}-\mathrm{DMSO}\right) \delta_{\mathrm{C}} 154.5,149.6,139.6,134.9$, 133.6, 132.9, 129.1, 127.5, 127.0, 122.7, 121.8, 118.6, 117.1, 114.8, 114.4, 83.1, 78.7, 78.5, 49.6,* 46.0, 27.5, 27.4, 22.1, 12.7; HRMS m/z (ESI ${ }^{+}$ Found: 550.29100, $\mathrm{C}_{31} \mathrm{H}_{40} \mathrm{~N}_{3} \mathrm{O}_{6}$ requires $[\mathrm{M}+\mathrm{H}]^{+} 550.29116$; LRMS $\left(\mathrm{ESI}^{+}\right)$ $572\left([\mathrm{M}+\mathrm{Na}]^{+}, 10 \%\right), 367(18 \%), 277$ (9\%), 248 (18\%), 225 (100\%), 186 (57\%); HPLC Method A, Retention time - 11.7 min, 99\%. *Signal for hydroxamic acid carbonyl quaternary carbon not observed, signal at $49.6 \mathrm{ob}$ served by ${ }^{1} \mathrm{H}-{ }^{13} \mathrm{C}$ HMBC correlation see SI for details.

(E)-tert-Butyl-3-(2-((tert-butoxycarbonyl) (4-(3-(( (1-methyl-2-nitro-1Himidazol-5-yl)methoxy)amino)-3-oxoprop-1-en-1-yl)benzyl)amino)ethyl)-2-methyl-1H-indole-1-carboxylate (S11)

A $60 \%$ dispersion of sodium hydride in mineral oil $(34 \mathrm{mg}, 0.85 \mathrm{mmol}$, $1.5 \mathrm{eq})$ was added to a solution of $27(0.31 \mathrm{~g}, 0.57 \mathrm{mmol}, 1.0 \mathrm{eq})$ in $N, N$-dimethylformamide $(1.5 \mathrm{~mL})$ at $-5^{\circ} \mathrm{C}$ and stirred for $10 \mathrm{~min}$. (1-methyl-2-nitro-imidazol-5-yl)methyl chloride (15) $(0.11 \mathrm{~g}, 0.62 \mathrm{mmol}, 1.1 \mathrm{eq})$ was added, then the reaction mixture was warmed to rt and stirred for $18 \mathrm{~h}$. The reaction was diluted with ethyl acetate $(50 \mathrm{~mL})$, quenched with an aqueous $1 \mathrm{M}$ solution of hydrochloric acid $(5 \mathrm{~mL})$ and washed with a $10 \%$ aqueous solution of lithium chloride $(5 \times 100 \mathrm{~mL})$, brine $(50 \mathrm{~mL})$, dried $\left(\mathrm{MgSO}_{4}\right)$, filtered, and concentrated in vacuo. Purification by column chromatography, eluting with $0-2.5 \%$ ethanol:chloroform, yielded the title compound (S11) $(0.29 \mathrm{~g}, 86 \%)$ as a pale-yellow solid. $R_{f} 0.68$ (ethyl acetate); mp 140$142{ }^{\circ} \mathrm{C}$ (from dichloromethane/hexane); $\bar{\nu}_{\max }$ (thin film) $/ \mathrm{cm}^{-1} 3192,2976$, $1729,1687,1492,1460,1367,1326,1159,1137 ;{ }^{1} \mathrm{H}$ NMR at $363 \mathrm{~K}$ $\left(500 \mathrm{MHz},\left(\mathrm{D}_{6}\right.\right.$-DMSO) $\delta_{\mathrm{H}} 11.05(1 \mathrm{H}, \mathrm{s}), 8.00(1 \mathrm{H}, \mathrm{d}, J 8.0), 7.50(2 \mathrm{H}, \mathrm{d}, J$ 8.1), $7.48(1 \mathrm{H}, \mathrm{d}, J 15.8), 7.42(1 \mathrm{H}, \mathrm{d}, J 7.5), 7.25(2 \mathrm{H}, \mathrm{d}, J 8.1), 7.25(1 \mathrm{H}$, s), $7.21(1 \mathrm{H}, \mathrm{ddd}, J 8.0,7.3,1.4), 7.16(1 \mathrm{H}, \mathrm{ddd}, J 7.5,7.3,1.2), 6.44(1 \mathrm{H}, \mathrm{d}$, J15.8), $5.02(2 \mathrm{H}, \mathrm{s}), 4.41(2 \mathrm{H}, \mathrm{s}), 4.08(3 \mathrm{H}, \mathrm{s}), 3.34(2 \mathrm{H}, \mathrm{t}, J 7.3), 2.84(2 \mathrm{H}$, t, $J$ 7.3), $2.46(3 \mathrm{H}, \mathrm{s}), 1.64(9 \mathrm{H}, \mathrm{s}), 1.35(9 \mathrm{H}, \mathrm{s}) ;{ }^{13} \mathrm{C}$ NMR at $363 \mathrm{~K}$ (126 MHz, (D 6 -DMSO) $\delta_{\mathrm{C}} 163.6,{ }^{*} 154.4,149.5,145.9,{ }^{*} 140.0,139.4,134.9$, 133.1, 132.9, 132.4, 129.1, 129.0, 127.4, 127.2, 122.7, 121.8, 117.6, 117.1, $114.8,114.4,83.1,78.5,65.6,49.6,46.1,33.6,27.5,27.4,22.1,12.7$; HRMS $\mathrm{m} / z \quad\left(\mathrm{ESI}^{+}\right)$Found: 711.31117, $\mathrm{C}_{36} \mathrm{H}_{44} \mathrm{~N}_{6} \mathrm{O}_{8} \mathrm{Na}$ requires $[\mathrm{M}+\mathrm{Na}]^{+}$ 711.31128; LRMS (ESI') 678 ([M-H $\left.]^{-}, 100 \%\right), 409$ (9\%), 281 (9\%), 255 (13\%); HPLC Method B, Retention time - $12.6 \mathrm{~min}, 96 \%$. * Signals at 163.6 and 145.9 observed by ${ }^{1} \mathrm{H}^{13} \mathrm{C}$ HMBC correlation see SI for details.

(E)-2-(2-Methyl-1 $H$-indol-3-yl)- $N$-(4-(3-(((1-methyl-2-nitro-1 $H$-imidazol-5-yl)methoxy)amino)-3-oxoprop-1-en-1-yl)benzyl)ethan-1-aminium 2,2,2-trifluoroacetate (NI-Pano, CH-03, 1)

Trifluoroacetic acid $(13.9 \mathrm{~mL} \mathrm{~mL}, 20 \% \mathrm{~V} / \mathrm{v})$ was added dropwise to a rapidly stirred solution of $\mathbf{S} 1 \mathbf{1}(410 \mathrm{mg}, 0.696 \mathrm{mmol}, 1.0 \mathrm{eq})$ and triisopropylsilane $(30.6 \mu \mathrm{L}, 0.139 \mathrm{mmol}, 0.2 \mathrm{eq})$ in dichloromethane $(70 \mathrm{~mL})$. The reaction mixture was stirred for 55 mins then diluted with toluene $(1 \mathrm{~mL})$ and dried by azeotroping with toluene $(3 \times 1 \mathrm{~mL})$ in vacuo. Purification using column chromatography, eluting with $0-20 \%$ (70\% isopropanol in water solution):ethyl acetate, yielded the title compound (1) (303 mg, 61\%) as a pale yellow solid. Where necessary the compound was further purified by semipreparative HPLC (see general experimental, retention time - $11.4 \mathrm{~min}) . R f$ 0.32 ( $10 \%$ ethanol: chloroform); mp $108-110^{\circ} \mathrm{C}$ (from methanol); $\bar{v}_{\max }$ (thin film) $/ \mathrm{cm}^{-1}$; 3293, 2925, 2853, 1673, 1624, 1539, 1491, 1461, 1342, 1189,$1044 ;{ }^{1} \mathrm{H}$ NMR $\left(500 \mathrm{MHz}, \mathrm{CD}_{3} \mathrm{OD}\right) \delta_{\mathrm{H}} 7.59(2 \mathrm{H}, \mathrm{d}, J 7.9), 7.56(1 \mathrm{H}$, d, J 15.9), 7.47 (2H, d, J7.9), 7.39 (1H, d, J7.6), 7.24 (1H, d, J7.7), 7.19 $(1 \mathrm{H}, \mathrm{s}), 7.02(1 \mathrm{H}, \mathrm{dd}, J 7.7,7.5), 6.95(1 \mathrm{H}, \mathrm{dd}, J 7.6,7.5), 6.47(1 \mathrm{H}, \mathrm{d}, J$ 15.9), $5.03(2 \mathrm{H}, \mathrm{s}), 4.21(2 \mathrm{H}, \mathrm{s}), 4.13(3 \mathrm{H}, \mathrm{s}), 3.20(2 \mathrm{H}, \mathrm{t}, J 7.8), 3.09(2 \mathrm{H}$ $\mathrm{t}, J 7.8), 2.37(3 \mathrm{H}, \mathrm{s}) ;{ }^{13} \mathrm{C} \mathrm{NMR}\left(126 \mathrm{MHz}, \mathrm{CD}_{3} \mathrm{OD}\right) \delta_{\mathrm{C}} 166.1,163.1\left(\mathrm{q},{ }^{2} \mathrm{~J}_{\mathrm{CF}}\right.$ 34.2), 147.7, 141.7, 137.2, 137.0, 134.7, $134.0(2 \times \mathrm{C})$, ${ }^{*} 131.5,130.4,129.5$, $129.2,121.8,119.9,119.1,118.2$ ( $\left.q,{ }^{1} J_{\text {CF }} 294.2\right), 118.0,111.6,105.8,67.4$, 51.9, 48.9,* 35.1, 22.3, 11.3; HRMS $\mathrm{m} / z\left(\mathrm{ESI}^{+}\right)$Found: 489.22418 $\mathrm{C}_{26} \mathrm{H}_{29} \mathrm{~N}_{6} \mathrm{O}_{4}$ requires $[\mathrm{M}+\mathrm{H}]+489.22448$; LRMS $\left(\mathrm{ESI}^{+}\right) 489\left([\mathrm{M}+\mathrm{H}]^{+}\right.$, 100\%), 349 (9\%); HPLC Method B, Retention time - 7.3 min, 98-99\%, mean purity $98 \%$. HPLC Methods D and E were used where necessary. All batches used for biological testing were $>95 \%$ purity. All batches used for 
animal studies were $>99.9 \%$ purity. ${ }^{*}$ The signals at 48.9 and pair at 134.0 were observed by ${ }^{1} \mathrm{H}^{-13} \mathrm{C}$ HMBC correlation, see SI for details.

(E)-N-(4-(2-Carboxyvinyl)benzyl)-2-(2-methyl-1 $H$-indol-3-yl)ethan-1aminium 2,2,2-trifluoroacetate (Pano acid, S12)

Trifluoroacetic acid $(0.14 \mathrm{~mL}, 20 \% \mathrm{v} / \mathrm{V})$ was added dropwise to a rapidly stirred solution of $18(15 \mathrm{mg}, 0.028 \mathrm{mmol}, 1.0 \mathrm{eq})$ and triisopropylsilane $(1.2 \mu \mathrm{L}, 5.6 \mu \mathrm{mol}, 0.2 \mathrm{eq})$ in dichloromethane $(0.7 \mathrm{~mL})$. The reaction mixture was stirred for 65 mins then diluted with toluene $(1 \mathrm{~mL})$ and dried by azeotroping with toluene $(3 \times 1 \mathrm{~mL})$ in vacuo. Purification using column chromatography, eluting with 1:2:6 $\mathrm{H}_{2} \mathrm{O}$ :isopropyl alcohol:ethyl acetate, then $100 \%$ ethanol, yielded the title compound (S12) (7 mg, 78\%) as a colorless solid. $\mathrm{R}_{f} 0.37$ (1:2:6 $\mathrm{H}_{2} \mathrm{O}$ :isopropyl alcohol:ethyl acetate); mp 95$97^{\circ} \mathrm{C}$ (from methanol); $\bar{v}_{\max }$ (thin film) $/ \mathrm{cm}^{-1} ; 3398,3032,2829,1672,1462$, 1426, 1198, 1139; ${ }^{1} \mathrm{H}$ NMR (500 MHz, CD $\left.{ }_{3} \mathrm{OD}\right) \delta_{\mathrm{H}} 7.66(2 \mathrm{H}, \mathrm{d}, J 8.3), 7.64$ $(1 \mathrm{H}, \mathrm{d}, J 16.0), 7.50(2 \mathrm{H}, \mathrm{d}, J 8.3), 7.41(1 \mathrm{H}, \mathrm{ddd}, J 8.0,1.1,1.0), 7.26(1 \mathrm{H}$, ddd, J8.1, 1.1, 1.0), 7.03 (1H, ddd, J8.1, 7.1, 1.1), 6.97 (1H, ddd, J8.0, 7.1, $1.1), 6.54$ (1H, d, J16.0), $4.24(2 \mathrm{H}, \mathrm{s}), 3.26-3.19(2 \mathrm{H}, \mathrm{m}), 3.15-3.07(2 \mathrm{H}$, m), $2.39(3 \mathrm{H}, \mathrm{s}) ;{ }^{13} \mathrm{C}$ NMR $\left(126 \mathrm{MHz}, \mathrm{CD}_{3} \mathrm{OD}\right) \delta \mathrm{C} 170.8,163.1(\mathrm{q}, 2 \mathrm{JCF}$ $35.0), 144.1,137.3$, 137.2, 134.3, 134.0, 131.5, 129.7, 129.2, 122.0, 121.8, 119.9, 118.3 (q, ${ }^{1}$ JCF 293.2) 117.9, 111.6, 105.6, 51.8, 48.8*, 22.2, 11.3; HRMS m/z $\left(\mathrm{ESI}^{+}\right)$Found: $335.17539 \mathrm{C}_{21} \mathrm{H}_{23} \mathrm{~N}_{2} \mathrm{O}_{2}$ requires $[\mathrm{M}+\mathrm{H}]^{+}$ 335.17540; LRMS (ESI $\left.{ }^{-}\right) 369\left([\mathrm{M}+\mathrm{Cl}]^{-}, 100 \%\right), 333\left([\mathrm{M}-\mathrm{H}]^{-}, 36 \%\right)$; HPLC Method B, Retention time - $6.9 \mathrm{~min}, 97 \% .{ }^{*}$ Overlapped by solvent residual signal, see SI for expansion.

\section{ASSOCIATED CONTENT}

\section{Supporting Information}

The Supporting Information is available free of charge on the ACS Publications website.

Full synthetic schemes for all compounds and excluded figures. HPLC traces and NMR spectra for novel and final compounds (PDF).

\section{ABBREVIATIONS}

Ac-CoA, Acetyl-coenzyme A; Boc, tert-Butyloxycarbonyl; CDI, 1,1'Carbonyl diimidazole; CHK-1, Checkpoint kinase 1; DIPEA, $N, N$ Diisopropylethylamine; DMAP, $N, N$-Dimethylaminopyridine; DMF, $N, N$-Dimethylformamide; DMSO, Dimethylsulfoxide; DNA, Deoxyribonucleic acid; DNA-PK, DNA-dependent protein kinase; ESI, Electrospray ionization; HAP, Hypoxia-activated prodrug; HDAC, Histone deacetylase; HER2, Human epidermal growth factor receptor 2; HPLC, High-performance liquid chromatography; HRMS, High resolution mass spectrometry; $\mathrm{IC}_{50}$, half maximal inhibitory concentration; KAc, Acetyl-lysine; KDAC, Lysine deacetylase; LCMS, Liquid chromatography mass spectrometry; LRMS, Low resolution mass spectrometry; $\mathrm{mp}$, Melting point; NADPH-CYP reductase, Nicotinamide adenine dinucleotide phosphate dependent-Cytochrome P450 reductase; NMR, Nuclear Magnetic Resonance spectroscopy; PARP, Poly-ADP ribose polymerase; PTM, Post-translational modification; PyBOP, benzotriazol-1-yl-oxytripyrrolidinophosphonium hexafluorophosphate; $\mathrm{R} f$, Retention factor; rt, Room temperature; TFA, Trifluoroacetic acid; THF, Tetrahydrofuran; TIPS-H, Triisopropylsilane.

\section{REFERENCES}

1. Diehl, K. L.; Muir, T. W., Chromatin as a key consumer in the metabolite economy. Nat. Chem. Biol. 2020, 16, 620-629.

2. Allfrey, V. G.; Faulkner, R.; Mirsky, A. E., Acetylation and methylation of histones and their possible role in the regulation of rna synthesis. Proc. Natl. Acad. Sci. 1964, 51, 786.

3. Choudhary, C.; Kumar, C.; Gnad, F.; Nielsen, M. L.; Rehman, M.; Walther, T. C.; Olsen, J. V.; Mann, M., Lysine acetylation targets protein complexes and co-regulates major cellular functions. Science 2009, 325, 834.
4. $\quad$ Choudhary, C.; Weinert, B. T.; Nishida, Y.; Verdin, E.; Mann, M., The growing landscape of lysine acetylation links metabolism and cell signalling. Nat. Rev. Mol. Cell Biol. 2014, 15, 536-550.

5. Fischer, C.; Leithner, K.; Wohlkoenig, C.; Quehenberger, F.; Bertsch, A.; Olschewski, A.; Olschewski, H.; Hrzenjak, A., Panobinostat reduces hypoxia-induced cisplatin resistance of non-small cell lung carcinoma cells via hif- $1 \alpha$ destabilization. Molecular Cancer 2015, 14, 4.

6. Schiedel, M.; Conway, S. J., Small molecules as tools to study the chemical epigenetics of lysine acetylation. Curr. Opin. Chem. Biol. 2018, 45, 166-178.

$7 . \quad$ Brand, M.; Measures, A. R.; Wilson, B. G.; Cortopassi, W. A.; Alexander, R.; Höss, M.; Hewings, D. S.; Rooney, T. P.; Paton, R. S.; Conway, S. J., Small molecule inhibitors of bromodomain-acetyl-lysine interactions. ACS Chem. Biol. 2015, 10, 22-39.

8. Hewings, D. S.; Rooney, T. P.; Jennings, L. E.; Hay, D. A.; Schofield, C. J.; Brennan, P. E.; Knapp, S.; Conway, S. J., Progress in the development and application of small molecule inhibitors of bromodomain-acetyl-lysine interactions. J. Med. Chem. 2012, 55, 9393-413.

9. Jennings, L. E.; Measures, A. R.; Wilson, B. G.; Conway, S. J., Phenotypic screening and fragment-based approaches to the discovery of small-molecule bromodomain ligands. Future Med Chem 2014, 6, 179-204.

10. Schiedel, M.; Moroglu, M.; Ascough, D. M. H.; Chamberlain, A. E. R.; Kamps, J.; Sekirnik, A. R.; Conway, S. J., Chemical epigenetics: The impact of chemical and chemical biology techniques on bromodomain target validation. Angew. Chem. Int. Ed. Engl. 2019, 58, 17930-17952.

11. Ropero, S.; Esteller, M., The role of histone deacetylases (hdacs) in human cancer. Molecular Oncology 2007, 1, 19-25.

12. Mariadason, J. M., Hdacs and hdac inhibitors in colon cancer. Epigenetics 2008, 3, 28-37.

13. Damaskos, C.; Valsami, S.; Kontos, M.; Spartalis, E.; Kalampokas, T.; Kalampokas, E.; Athanasiou, A.; Moris, D.; Daskalopoulou, A.; Davakis, S.; Tsourouflis, G.; Kontzoglou, K.; Perrea, D.; Nikiteas, N.; Dimitroulis, D., Histone deacetylase inhibitors: An attractive therapeutic strategy against breast cancer. Anticancer Res. 2017, 37, 35-46.

14. Suraweera, A.; O’Byrne, K. J.; Richard, D. J., Combination therapy with histone deacetylase inhibitors (hdaci) for the treatment of cancer: Achieving the full therapeutic potential of hdaci. Frontiers in Oncology 2018, 8.

15. Li, Z.; Zhu, W.-G., Targeting histone deacetylases for cancer therapy: From molecular mechanisms to clinical implications. International Journal of Biological Sciences 2014, $10,757-770$

16. Daniel, K. B.; Sullivan, E. D.; Chen, Y.; Chan, J. C.; Jennings, P. A.; Fierke, C. A.; Cohen, S. M., Dual-mode hdac prodrug for covalent modification and subsequent inhibitor release. J. Med. Chem. 2015, 58, 4812-4821.

17. Gryder, B. E.; Sodji, Q. H.; Oyelere, A. K., Targeted cancer therapy: Giving histone deacetylase inhibitors all they need to succeed. Future Medicinal Chemistry 2012, 4, 505-524.

18. Witt, O.; Deubzer, H. E.; Milde, T.; Oehme, I., Hdac family: What are the cancer relevant targets? Cancer Lett. 2009, 277, 8-21.

19. Bieliauskas, A. V.; Pflum, M. K. H., Isoform-selective histone deacetylase inhibitors. Chem. Soc. Rev. 2008, 37, 14021413 .

20. Roche, J.; Bertrand, P., Inside hdacs with more selective hdac inhibitors. Eur. J. Med. Chem. 2016, 121, 451-483.

21. Liu, S.; Zhang, K.; Zhu, Q.; Shen, Q.; Zhang, Q.; Yu, J.; Chen, Y.; Lu, W., Synthesis and biological evaluation of paclitaxel 
and vorinostat co-prodrugs for overcoming drug resistance in cancer therapy in vitro. Bioorg. Med. Chem. 2019, 27, 1405-1413. 22. Schlimme, S.; Hauser, A. T.; Carafa, V.; Heinke, R.; Kannan, S.; Stolfa, D. A.; Cellamare, S.; Carotti, A.; Altucci, L.; Jung, M.; Sippl, W., Carbamate prodrug concept for hydroxamate hdac inhibitors. ChemMedChem 2011, 6, 1193-8.

23. Bhagat, S. D.; Singh, U.; Mishra, R. K.; Srivastava, A., An endogenous reactive oxygen species (ros)-activated histone deacetylase inhibitor prodrug for cancer chemotherapy. ChemMedChem 2018, 13, 2073-2079.

24. Liao, Y.; Xu, L.; Ou, S.; Edwards, H.; Luedtke, D.; Ge, Y.; Qin, Z., H(2)o(2)/peroxynitrite-activated hydroxamic acid hdac inhibitor prodrugs show antileukemic activities against aml cells. ACS Med Chem Lett 2018, 9, 635-640.

25. Needham, L. A.; Davidson, A. H.; Bawden, L. J.; Belfield, A.; Bone, E. A.; Brotherton, D. H.; Bryant, S.; Charlton, M. H.; Clark, V. L.; Davies, S. J.; Donald, A.; Day, F. A.; Krige, D.; Legris, V.; McDermott, J.; McGovern, Y.; Owen, J.; Patel, S. R.; Pintat, S.; Testar, R. J.; Wells, G. M. A.; Moffat, D.; Drummond, A. H., Drug targeting to monocytes and macrophages using esterase-sensitive chemical motifs. J. Pharmacol. Exp. Ther. 2011, 339, 132-142.

26. Ossenkoppele, G. J.; Lowenberg, B.; Zachee, P.; Vey, N.; Breems, D.; Van de Loosdrecht, A. A.; Davidson, A. H.; Wells, G.; Needham, L.; Bawden, L.; Toal, M.; Hooftman, L.; Debnam, P. M., A phase $i$ first-in-human study with tefinostat - a monocyte/macrophage targeted histone deacetylase inhibitor - in patients with advanced haematological malignancies. $\mathrm{Br} . \mathrm{J}$. Haematol. 2013, 162, 191-201.

27. Szymanski, W.; Ourailidou, M. E.; Velema, W. A.; Dekker, F. J.; Feringa, B. L., Light-controlled histone deacetylase (hdac) inhibitors: Towards photopharmacological chemotherapy. Chemistry - A European Journal 2015, 21, 16517-16524.

28. Rubio-Ruiz, B.; Weiss, J. T.; Unciti-Broceta, A., Efficient palladium-triggered release of vorinostat from a bioorthogonal precursor. J. Med. Chem. 2016, 59, 9974-9980.

29. Calder, E. D. D.; Skwarska, A.; Sneddon, D.; Folkes, L. K.; Mistry, I. N.; Conway, S. J.; Hammond, E. M., Hypoxiaactivated pro-drugs of the kdac inhibitor vorinostat (saha). Tetrahedron 2020, 76, 131170.

30. McKeown, S. R., Defining normoxia, physoxia and hypoxia in tumours-implications for treatment response. $\mathrm{Br} . \mathrm{J}$. Radiol. 2014, 87, 20130676.

31. Hammond, E. M.; Asselin, M. C.; Forster, D.; O'Connor, J. P. B.; Senra, J. M.; Williams, K. J., The meaning, measurement and modification of hypoxia in the laboratory and the clinic. Clinical Oncology 2014, 26, 277-288.

32. Jing, X.; Yang, F.; Shao, C.; Wei, K.; Xie, M.; Shen, H.; Shu, Y., Role of hypoxia in cancer therapy by regulating the tumor microenvironment. Molecular Cancer 2019, 18, 157.

33. Gilkes, D. M.; Semenza, G. L.; Wirtz, D., Hypoxia and the extracellular matrix: Drivers of tumour metastasis. Nat. Rev. Cancer 2014, 14, 430-439.

34. Grimes, D. R.; Partridge, M., A mechanistic investigation of the oxygen fixation hypothesis and oxygen enhancement ratio. Biomedical physics \& engineering express 2015, 1, 045209-045209.

35. Ramachandran, S.; Ient, J.; Göttgens, E. L.; Krieg, A. J.; Hammond, E. M., Epigenetic therapy for solid tumors: Highlighting the impact of tumor hypoxia. Genes (Basel) 2015, 6, 935-56.

36. Jan, L., Tissue transport of anti-cancer drugs. Curr. Pharm.Des. 2002, 8, 1987-1993.

37. Gatti, L.; Zunino, F., Overview of tumor cell chemoresistance mechanisms. Methods Mol. Med. 2005, 111, 12748.
38. Gottesman, M. M., Mechanisms of cancer drug resistance. Annu. Rev. Med. 2002, 53, 615-627.

39. Harris, A. L., Hypoxia - a key regulatory factor in tumour growth. Nat. Rev. Cancer 2002, 2, 38-47.

40. Mistry, I. N.; Thomas, M.; Calder, E. D. D.; Conway, S. J.; Hammond, E. M., Clinical advances of hypoxia-activated prodrugs in combination with radiation therapy. Int. J. Radiat. Oncol., Biol., Phys. 2017, 98, 1183-1196.

41. Graham, K.; Unger, E., Overcoming tumor hypoxia as a barrier to radiotherapy, chemotherapy and immunotherapy in cancer treatment. Int J Nanomedicine 2018, 13, 6049-6058.

42. Spiegelberg, L.; Houben, R.; Niemans, R.; de Ruysscher, D.; Yaromina, A.; Theys, J.; Guise, C. P.; Smaill, J. B.; Patterson, A. V.; Lambin, P.; Dubois, L. J., Hypoxia-activated prodrugs and (lack of) clinical progress: The need for hypoxia-based biomarker patient selection in phase iii clinical trials. Clinical and Translational Radiation Oncology 2019, 15, 62-69.

43. Fallah, J.; Rini, B. I., Hif inhibitors: Status of current clinical development. Current Oncology Reports 2019, 21, 6.

44. Zeng, Y.; Ma, J.; Zhan, Y.; Xu, X.; Zeng, Q.; Liang, J.; Chen, X., Hypoxia-activated prodrugs and redox-responsive nanocarriers. International journal of nanomedicine 2018, 13, 6551-6574.

45. O'Connor, L. J.; Cazares-Körner, C.; Saha, J.; Evans, C. N.; Stratford, M. R.; Hammond, E. M.; Conway, S. J., Design, synthesis and evaluation of molecularly targeted hypoxia-activated prodrugs. Nat. Protoc. 2016, 11, 781-94.

46. Portwood, S.; Lal, D.; Hsu, Y.-C.; Vargas, R.; Johnson, M. K.; Wetzler, M.; Hart, C. P.; Wang, E. S., Activity of the hypoxia-activated prodrug, th-302, in preclinical human acute myeloid leukemia models. Clin. Cancer. Res. 2013, 19, 6506-6519. 47. Foehrenbacher, A.; Patel, K.; Abbattista, M.; Guise, C.; Secomb, T.; Wilson, W.; Hicks, K., The role of bystander effects in the antitumor activity of the hypoxia-activated prodrug pr-104. Frontiers in Oncology 2013, 3.

48. Cazares-Körner, C.; Pires, I. M.; Swallow, I. D.; Grayer, S. C.; O'Connor, L. J.; Olcina, M. M.; Christlieb, M.; Conway, S. J.; Hammond, E. M., Ch-01 is a hypoxia-activated prodrug that sensitizes cells to hypoxia/reoxygenation through inhibition of chk1 and aurora a. ACS Chem. Biol. 2013, 8, 1451-9.

49. Baran, N.; Konopleva, M., Molecular pathways: Hypoxia-activated prodrugs in cancer therapy. Clin. Cancer. Res. 2017, 23, 2382-2390.

50. Plummer, R.; Stephens, P.; Aissat-Daudigny, L.; Cambois, A.; Moachon, G.; Brown, P. D.; Campone, M., Phase 1 dose-escalation study of the parp inhibitor cep-9722 as monotherapy or in combination with temozolomide in patients with solid tumors. Cancer Chemother. Pharmacol. 2014, 74, 257-265.

51. Lindquist, K. E.; Cran, J.; Kordic, K.; Chua, P. C.; Winters, G. C.; Tan, J. S.; Lozada, J.; Kyle, A. H.; Evans, J. W.; Minchinton, A. I. In Selective radiosensitization of hypoxic cells using bcca621c: A novel hypoxia activated prodrug targeting DNA-dependent protein kinase, 2013.

52. Konsoula, R.; Jung, M., In vitro plasma stability, permeability and solubility of mercaptoacetamide histone deacetylase inhibitors. Int. J. Pharm. 2008, 361, 19-25.

53. Kelly, W. K.; O'Connor, O. A.; Krug, L. M.; Chiao, J. H.; Heaney, M.; Curley, T.; MacGregore-Cortelli, B.; Tong, W.; Secrist, J. P.; Schwartz, L.; Richardson, S.; Chu, E.; Olgac, S.; Marks, P. A.; Scher, H.; Richon, V. M., Phase i study of an oral histone deacetylase inhibitor, suberoylanilide hydroxamic acid, in patients with advanced cancer. Journal of Clinical Oncology 2005, 23, 3923-3931.

54. Mu, S.; Kuroda, Y.; Shibayama, H.; Hino, M.; Tajima, T.; Corrado, C.; Lin, R.; Waldron, E.; Binlich, F.; Suzuki, K., Panobinostat $\mathrm{pk} / \mathrm{pd}$ profile in combination with bortezomib and 
dexamethasone in patients with relapsed and relapsed/refractory multiple myeloma. Eur. J. Clin. Pharmacol. 2016, 72, 153-161.

55. Skwarska, A.; Calder, E. D. D.; Sneddon, D.; Mistry, I. N.; Bolland, H.; Folkes, L. K.; Conway, S. J.; Hammond, E. M., Development and pre-clinical testing of a novel hypoxia-activated pan kdac inhibitor. Cell Chemical Biology 2020.

56. Collins, S. L.; Saha, J.; Bouchez, L. C.; Hammond, E. M.; Conway, S. J., Hypoxia-activated, small-molecule-induced gene expression. ACS Chem. Biol. 2018, 13, 3354-3360.

57. Conway, S.; Oconnor, L.; Hammond, E.; O'Connor, L. New fluorogenic compound comprising fluorogenic component and biologically active component i.E. Bound to fluorogenic component at active binding position, useful to treat e.G. Hypoxiarelated disease including tumor and kidney disease. WO2015071665-A1; US2016264558-A1; EP3068767-A1.

58. Hunter, F. W.; Wouters, B. G.; Wilson, W. R., Hypoxiaactivated prodrugs: Paths forward in the era of personalised medicine. Br. J. Cancer 2016, 114, 1071-1077.

59. Sharma, A.; Arambula, J. F.; Koo, S.; Kumar, R.; Singh, H.; Sessler, J. L.; Kim, J. S., Hypoxia-targeted drug delivery. Chem. Soc. Rev. 2019, 48, 771-813.

60. Phillips, R. M., Targeting the hypoxic fraction of tumours using hypoxia-activated prodrugs. Cancer Chemother. Pharmacol. 2016, 77, 441-457.

61. Chen, S.; Zhang, P.; Chen, H.; Zhang, P.; Yu, Y.; Gan, Z., An improved and efficient synthesis of panobinostat. J. Chem. Res. 2018, 42, 471-473.

62. Grandberg, I. I., Indolylalkylamines from arylhydrazines and $\gamma$ - or $\delta$-halocarbonyl compounds (review). Chem. Heterocycl. Compd.(N. Y., NY, U.S.) 1974, 10, 501-510.

63. Grandberg, I. I.; Zuyanova, T. I., Indoles. Chem. Heterocycl. Compd. (N. Y., NY, U. S.) 1971, 4, 632-633.

64. Slade, J.; Parker, D.; Girgis, M.; Wu, R.; Joseph, S.; Repič, O., Optimization and scale-up of the grandberg synthesis of 2-methyltryptamine. Org. Process Res. Dev. 2007, 11, 721-725.

65. O'Connor, L. J.; Cazares-Körner, C.; Saha, J.; Evans, C. N. G.; Stratford, M. R. L.; Hammond, E. M.; Conway, S. J., Design, synthesis and evaluation of molecularly targeted hypoxia-activated prodrugs. Nature Protocols 2016, 11, 781-794.

66. Arts, J.; King, P.; Marien, A.; Floren, W.; Belien, A.; Janssen, L.; Pilatte, I.; Roux, B.; Decrane, L.; Gilissen, R.; Hickson, I.; Vreys, V.; Cox, E.; Bol, K.; Talloen, W.; Goris, I.; Andries, L.; Du Jardin, M.; Janicot, M.; Page, M.; van Emelen, K.; Angibaud, P., Jnj-26481585, a novel "second-generation" oral histone deacetylase inhibitor, shows broad-spectrum preclinical antitumoral activity. Clin. Cancer. Res. 2009, 15, 6841-51.

67. Butler, K. V.; Kalin, J.; Brochier, C.; Vistoli, G.; Langley, B.; Kozikowski, A. P., Rational design and simple chemistry yield a superior, neuroprotective hdac6 inhibitor, tubastatin a. J. Am. Chem. Soc. 2010, 132, 10842-10846.

68. Ho, Y.-H.; Wang, K.-J.; Hung, P.-Y.; Cheng, Y.-S.; Liu, J.-R.; Fung, S.-T.; Liang, P.-H.; Chern, J.-W.; Yu, C.-W., A highly hdac6-selective inhibitor acts as a fluorescent probe. Org. Biomol. Chem. 2018, 16, 7820-7832.

69. Wagner, F. F.; Olson, D. E.; Gale, J. P.; Kaya, T.; Weïwer, M.; Aidoud, N.; Thomas, M.; Davoine, E. L.; Lemercier, B. C.; Zhang, Y.-L.; Holson, E. B., Potent and selective inhibition of histone deacetylase 6 (hdac6) does not require a surface-binding motif. J. Med. Chem. 2013, 56, 1772-1776.

70. Huang, F.-I.; Wu, Y.-W.; Sung, T.-Y.; Liou, J.-P.; Lin, M.-H.; Pan, S.-L.; Yang, C.-R., Mpt0g413, a novel hdac6-selective inhibitor, and bortezomib synergistically exert anti-tumor activity in multiple myeloma cells. Frontiers in Oncology 2019, 9.

71. Lee, J.-H.; Mahendran, A.; Yao, Y.; Ngo, L.; VentaPerez, G.; Choy, M. L.; Kim, N.; Ham, W.-S.; Breslow, R.; Marks,
P. A., Development of a histone deacetylase 6 inhibitor and its biological effects. Proc. Natl. Acad. Sci. 2013, 110, 15704-15709.

72. Bergman, J. A.; Woan, K.; Perez-Villarroel, P.; Villagra, A.; Sotomayor, E. M.; Kozikowski, A. P., Selective histone deacetylase 6 inhibitors bearing substituted urea linkers inhibit melanoma cell growth. J. Med. Chem. 2012, 55, 9891-9899.

73. Witter, D. J.; Harrington, P.; Wilson, K. J.; Chenard, M.; Fleming, J. C.; Haines, B.; Kral, A. M.; Secrist, J. P.; Miller, T. A., Optimization of biaryl selective hdac1\&2 inhibitors (shi-1:2). Bioorg. Med. Chem. Lett. 2008, 18, 726-731.

74. Gao, S.; Zang, J.; Gao, Q.; Liang, X.; Ding, Q.; Li, X.; $\mathrm{Xu}, \mathrm{W}$.; Chou, C. J.; Zhang, Y., Design, synthesis and anti-tumor activity study of novel histone deacetylase inhibitors containing isatin-based caps and o-phenylenediamine-based zinc binding groups. Biorg. Med. Chem. 2017, 25, 2981-2994.

75. Pangborn, A. B.; Giardello, M. A.; Grubbs, R. H.; Rosen, R. K.; Timmers, F. J., Safe and convenient procedure for solvent purification. Organometallics 1996, 15, 1518-1520.

76. Fulmer, G. R.; Miller, A. J. M.; Sherden, N. H.; Gottlieb, H. E.; Nudelman, A.; Stoltz, B. M.; Bercaw, J. E.; Goldberg, K. I., Nmr chemical shifts of trace impurities: Common laboratory solvents, organics, and gases in deuterated solvents relevant to the organometallic chemist. Organometallics 2010, 29, 2176-2179.

77. Righi, M.; Topi, F.; Bartolucci, S.; Bedini, A.; Piersanti, G.; Spadoni, G., Synthesis of tryptamine derivatives via a direct, one-pot reductive alkylation of indoles. The Journal of Organic Chemistry 2012, 77, 6351-6357.

78. Hajipour, A. R.; Karami, K.; Tavakoli, G., Heck coupling reaction using monomeric ortho-palladated complex of 4-methoxybenzoylmethylenetriphenylphosphorane under microwave irradiation. Appl. Organomet. Chem. 2010, 24, 798-804.

79. $\mathrm{Xu}, \mathrm{Y}$. Preparation of panobinostat involves reacting ((((methyl-1h-indolyl-ethyl)amino)methyl)phenyl)methyl acrylate hydrochloride with hydroxylamine and obtaining n-hydroxy(((((methyl-1h-indol-3-yl)ethyl)amino)methyl)phenyl)acrylamide. CN106674079-A.

80. Wang, M.-Z.; Xu, H.; Liu, T.-W.; Feng, Q.; Yu, S.-J.; Wang, S.-H.; Li, Z.-M., Design, synthesis and antifungal activities of novel pyrrole alkaloid analogs. Eur. J. Med. Chem. 2011, 46, 1463-1472.

81. Brady, O. L.; Klein, L., Cxxviii.-the isomerism of the oximes. Part xxix. Isomeric p-nitrobenzyl and methyl ethers of some aldoximes. Journal of the Chemical Society (Resumed) 1927, 874-894.

82. Singha, A. S. M., B. N., Indian J. Chem., Sect. B: Org. Chem. Incl. Med. Chem. 1982, 21,361-363.

83. Winn, B. A.; Shi, Z.; Carlson, G. J.; Wang, Y.; Nguyen, B. L.; Kelly, E. M.; Ross Iv, R. D.; Hamel, E.; Chaplin, D. J.; Trawick, M. L.; Pinney, K. G., Bioreductively activatable prodrug conjugates of phenstatin designed to target tumor hypoxia. Bioorg. Med. Chem. Lett. 2017, 27, 636-641.

84. Wiles, C.; Watts, P.; Haswell, S. J., Clean and selective oxidation of aromatic alcohols using silica-supported jones' reagent in a pressure-driven flow reactor. Tetrahedron Lett. 2006, 47, 5261-5264.

85. Sohda, T. T., JP), Taketomi, Shigehisa (Ikeda, JP), Oda, Tsuneo (Ibaraki, JP) Phosphonic acid compounds, their production and use. 1998

86. Sapountzis, I.; Dube, H.; Lewis, R.; Gommermann, N.; Knochel, P., Synthesis of functionalized nitroarylmagnesium halides via an iodine-magnesium exchange. The Journal of Organic Chemistry 2005, 70, 2445-2454.

87. Parveen, I.; Naughton, D. P.; Whish, W. J. D.; Threadgill, M. D., 2-nitroimidazol-5-ylmethyl as a potential bioreductively activated prodrug system: Reductively triggered release of the parp 
inhibitor 5-bromoisoquinolinone. Bioorg. Med. Chem. Lett. 1999, 9, 2031-2036.

88. O'Connor, L. J.; Cazares-Korner, C.; Saha, J.; Evans, C.

N. G.; Stratford, M. R. L.; Hammond, E. M.; Conway, S. J.,

Efficient synthesis of 2-nitroimidazole derivatives and the bioreductive clinical candidate evofosfamide (th-302). Organic Chemistry Frontiers 2015, 2, 1026-1029.<smiles>C=Cc1c(C)[nH]c2ccccc12</smiles>

$\mathrm{H}$

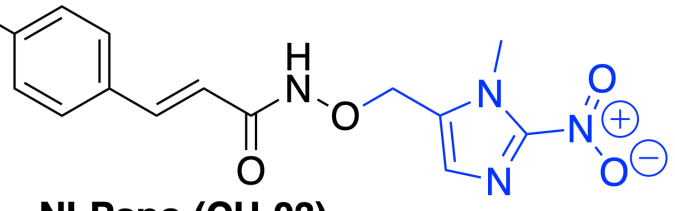

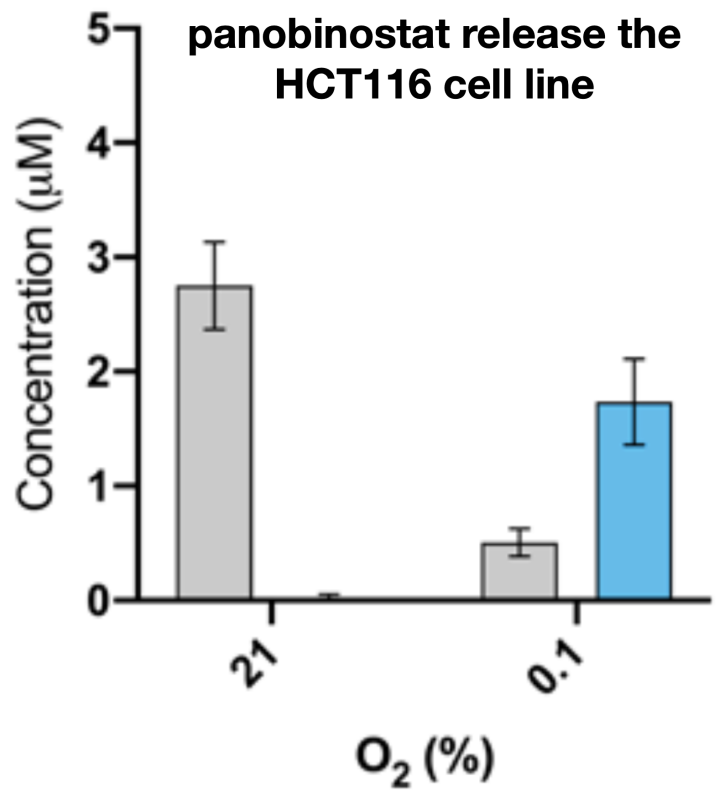
in hypoxia

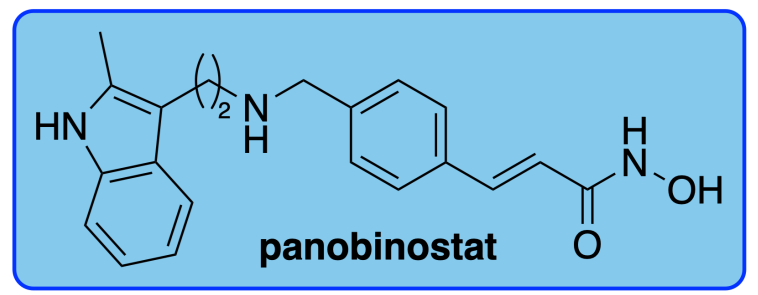

